\title{
The Río de la Plata craton and the assembly of SW Gondwana
}

\author{
C.W. Rapela ${ }^{a, *}$, R.J. Pankhurst ${ }^{b}$, C. $^{\text {Casquet }}{ }^{\text {c }}$, C.M. Fanning ${ }^{\text {d }}$, E.G. Baldo ${ }^{\mathrm{e}}$, \\ J.M. González-Casado ${ }^{\mathrm{f}}, \mathrm{C}$. Galindo ${ }^{\mathrm{c}}$, J. Dahlquist ${ }^{\mathrm{g}}$ \\ a Centro de Investigaciones Geológicas, CONICET-UNLP, Calle 1 No. 644, 1900 La Plata, Argentina \\ b NERC Isotope Geosciences Laboratory, British Geological Survey, Keyworth, Nottingham NG12 5GG, UK \\ ' Departamento de Petrología y Geoquímica, Universidad Complutense, 28040 Madrid, Spain \\ d Research School of Earth Sciences, The Australian National University, Mills Road, Canberra, ACT 200, Australia

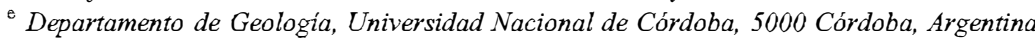 \\ ${ }^{\mathrm{f}}$ Departamento de Geología y Geoquímica, Universidad Autónoma, 28049 Madrid, Spain \\ ' CRILAR-CONICET, 5301 Anillaco, La Rioja, Argentin
}

\begin{abstract}
The extent and nature of the Archaean Palaeoproterozoic craton of Río de la Plata of southern South America, a major but poorly understood crustal component in Ncoproterozoic plate reconstructions, as well as the depositional, metamorphic and magmatic history of the surrounding orogenic belts, are reviewed and reassessed, in part through the analysis of material recovered from deep boreholes in western Argentina that penetrated Palaeozoic cover into basement. U Pb SHRIMP zircon ages for these samples of $2162 \pm 6 \mathrm{Ma}$ (diorite), $2189 \pm 14 \mathrm{Ma}$ (amphibolitic schist) and 2088 $\pm 6 \mathrm{Ma}$ (granite) encompass the range of ages determined for the major Palaeoproterozoic orogenic events in the exposed parts of the craton close to the Atlantic coasts of Urugray and Argertiria. Taken together with the geochemical and Nd-isotope characteristics of these samules and an olivine gabbro from a further borehole that failed to yield zircon, these results strongly suggest that the Río de la Plata craton is extremely uniform in its dominant chrono-tectonic and lithological make-up, and that it extends westwards as far as the $535520 \mathrm{Ma}$ Parnpear orogenic belt, against which it probably has a fault contact.

$\mathrm{U} \mathrm{Pb}$ SHRIMP zircon detrital age patterns are presented for representative metasedimentary samples from the craton cover in the Tandilia belt of eastern Argentina, and from the Panpcan (Cambriar) and Famatinian (Ordovician) belts to the west of the craton. Whereas the oldest cover rocks in Tandilia clearly show material derived from the underlying craton, such detritus only appears in the younger (Ordovician) units to the west. Sedimentary protoliths in the Pampean belt were dominated by Neoproterozoic (broadly $\sim 600 \mathrm{Ma}$ ) and late Yeseproterozoic (broadly $\sim 1100 \mathrm{Ma}$ ) provenance, and derivation from the Río de la Plata craton is highly unlikely. Regional considerations, including previously published zircon data, palaeocurrent and structural data, suggest that these rocks must have had an origin within Gondwana-forming blocks, for which the closest identifiable sources are 'Brazilian' and 'African' (Namaqua Natal). Consequently, the preferred model for the Pampean orogeny is that the Río de la Plata craton reached its present position by large-scale dextral strike-slip movement against fore-arc sedimentary sequences that had developed on the southern and westem margins of the Kalahari craton during the Early Cambrian. In the final stage the displaced sedinientary sequences outboard of the RPC collided with the Mesoproterozoic Western Sierras Pampeanas terrane,
\end{abstract}

\footnotetext{
* Corresponding author. Tel.: +54 2214215677 ; fax: +54 2214827560 .

E-mail ddresses: crapela@cig.museo.unlp.edu.ar (C.W. Rapela), rjpt@nigl.nerc.ac.uk (R.J. Pankhurst), casquet@geo.ucm.es (C. Casquet), mark.fanning@anu.edu.au (C.M. Fanning).
} 
which was at the time attached to the large Amazonia craton and other smaller continental blocks, such as Arequipa Antofalla and Río Apa. Protracted relative displacement of the RPC after the Pampean Orogeny led to its final position.

Keywords: Río de la Plata craton; Gondwana assembly; Palaeoproterozoic; Neoproterozoic; Cambrian; Brasiliano orogeny; Pampean orogeny; $\mathrm{U}-\mathrm{Pb}$ zircon dating

\section{Introduction}

Recent palaeomagnetic studies suggest that West Gondwana was finally assembled in mid-Cambrian times as a result of the collision of the Amazonia, Río Apa and associated minor blocks against the São Francisco/Congo and Río de la Plata group of cratons including other minor blocks such as Paraná (Fig. 1) (Cordaru et al., 2003; Tohver et al., 2006; Trindade et al., 2006). If correct, this collision along the Transbrasiliano lineament implies a major revision of existing tectonic hypotheses for the amalgamation of southwest Gondwana and development

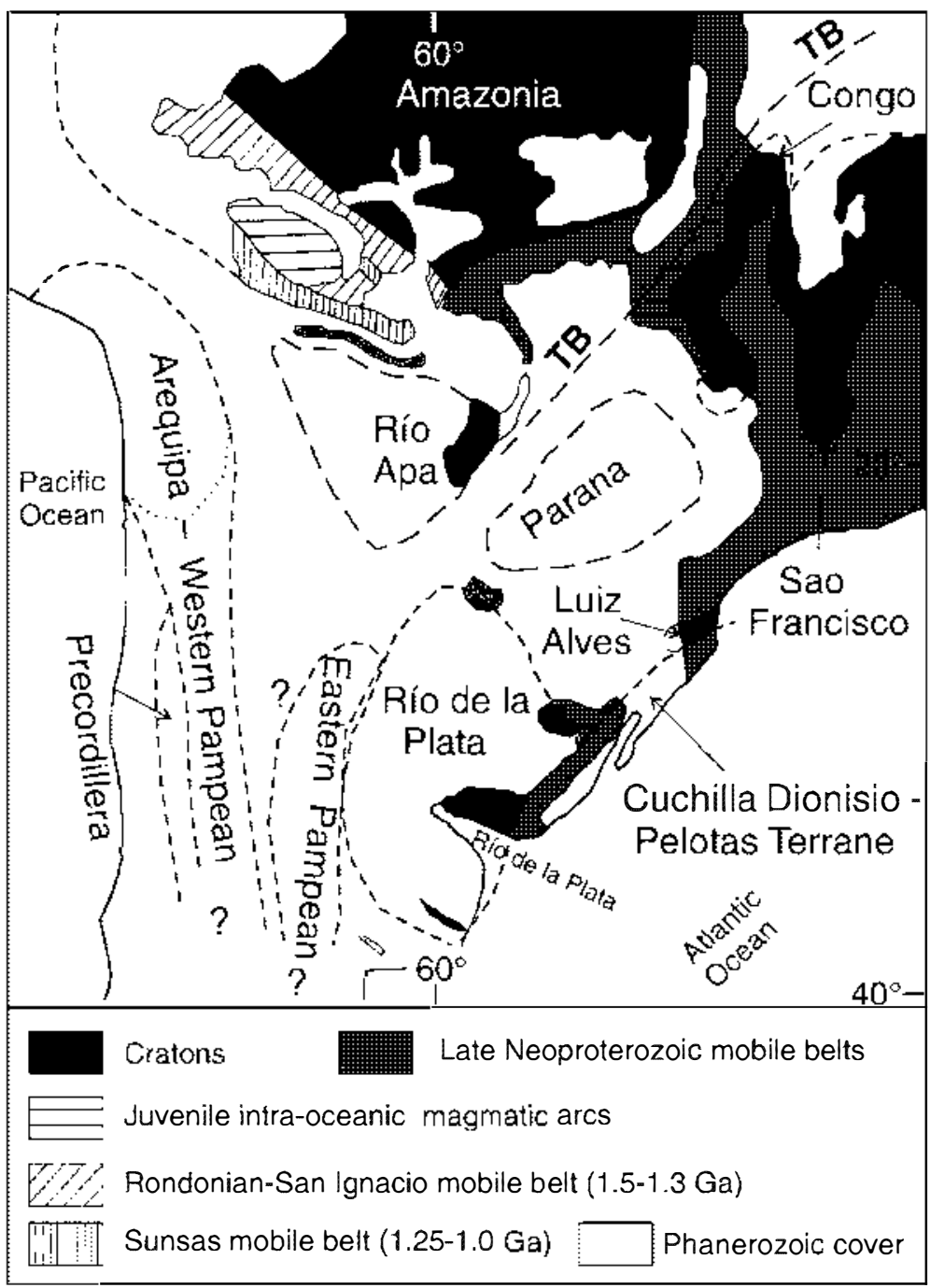

Fig. 1. Precambrian tectonic framework of central South America (modified from Kröner and Cordani, 2003; Cordani et al., 2003). Dashed lines indicate inferred boundaries of major crustal units beneath Phanerozoic cover. TB $=$ Transbrasiliano lineament. 


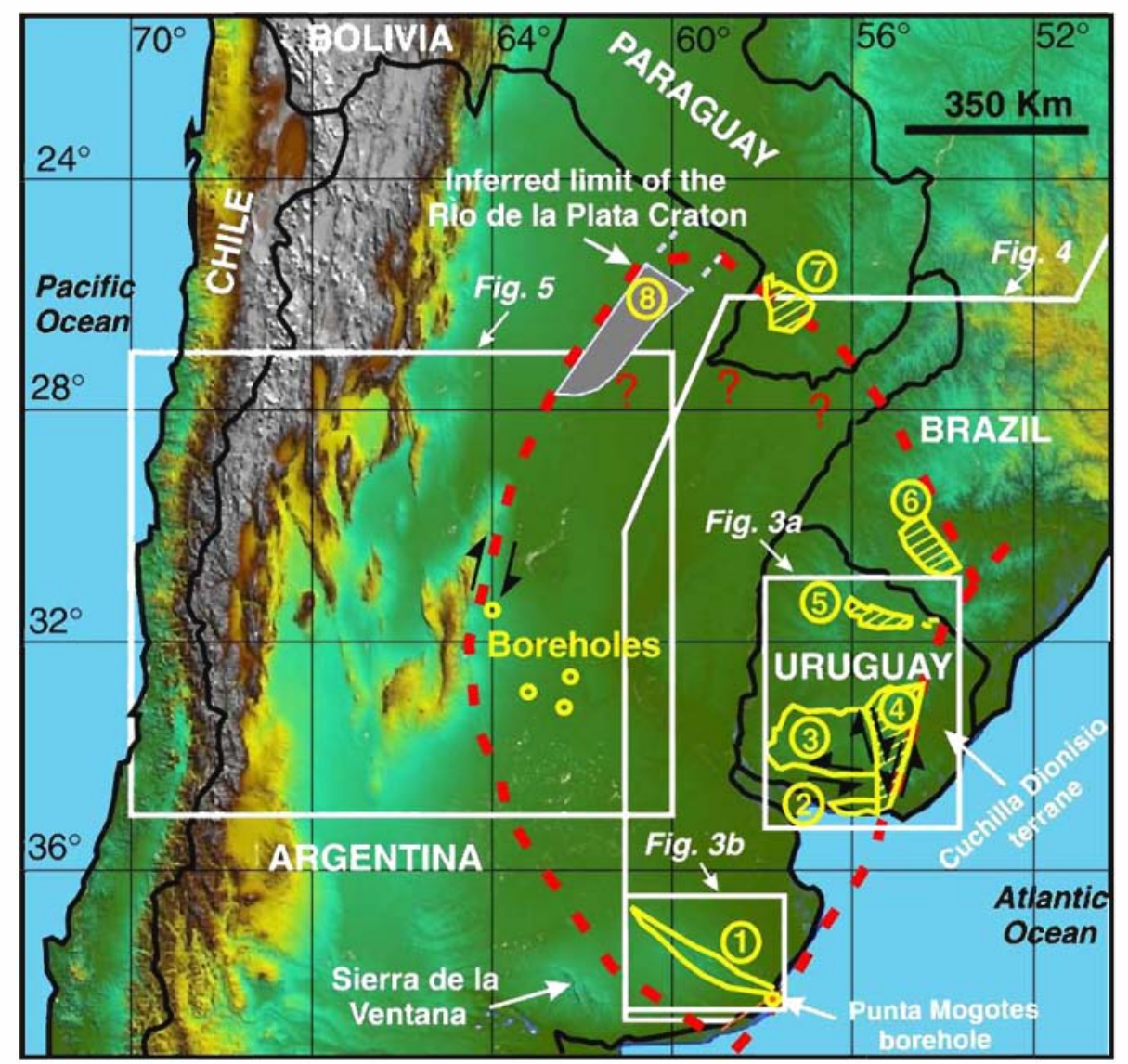

Fig. 2. Satellite image of central South America showing the inferred limit of the Río de la Plata craton and its main recognized units: (1) Tandilia belt, (2) Pando belt (Tandilia terrane), (3) Piedra Alta terrane, (4) Nico Pérez terrane, (5) Rivera block, (6) Tacuarembó block, (7) Asunción arch. Also shown are the subsurface Early Palaeozoic Las Breñas basin (8) and the location of boreholes in the Chacoparanense basin from which our new data were obtained (see text). The eastern sector of the craton is composed of Archaean and Palaeoproterozoic terranes that have been affected by Neoproterozoic orogenesis (hatched areas), while most of the RPC consist solely of Palaeoproterozoic igneous and meta-igneous complexes without Neoproterozoic overprint.

of the proto-Andean margin. The 535-520 Ma Pampean orogeny of the Eastern Sierras Pampeanas, which has been interpreted as due to parautochthonous terrane collision against the proto-Pacific margin of the supercontinent (Rapela et al., 1998), affected an area south of the westemmost end of the Transbrasiliano lineament (Trindade et al., 2006) (Fig. 1) and is another integral feature of West Gondwana assembly.

The Río de la Plata craton (RPC) has an important role in this scenario and is a key tectonic unit for testing these models. It is classically considered to be autochthonous Palaeoproterozoic continental crust in southwestem Gondwana (e.g. Ramos, 1988; Rapela, 2000). However its outcrops are restricted to type areas near the Atlantic margin of southern South America (Figs. 2-4), so hindering analysis of more exact tectonic and crustal growth models for Gondwana. Here we present high-quality
U-Pb SHRIMP data for zircon separates from samples from deep boreholes through the Chacoparanense basin, Córdoba province, $600-700 \mathrm{~km}$ west of the typical areas of the craton. Coupled with geochemical and $\mathrm{Nd}$ isotope data, and particularly with $\mathrm{U}-\mathrm{Pb}$ provenance age pattems obtained from Neoproterozoic and Lower Palaeozoic sedimentary and metasedimentary units deposited on and surrounding the craton, we are able to address and refine aspects of the following issues:

$1-$ the westward extension of the craton

2 - definition of the age and compositional characteristics of the RPC

3 - the role of the RPC as a source for the surrounding belts

4- the characteristics of the boundary between the craton and the proto-Andean Palaeozoic belts 

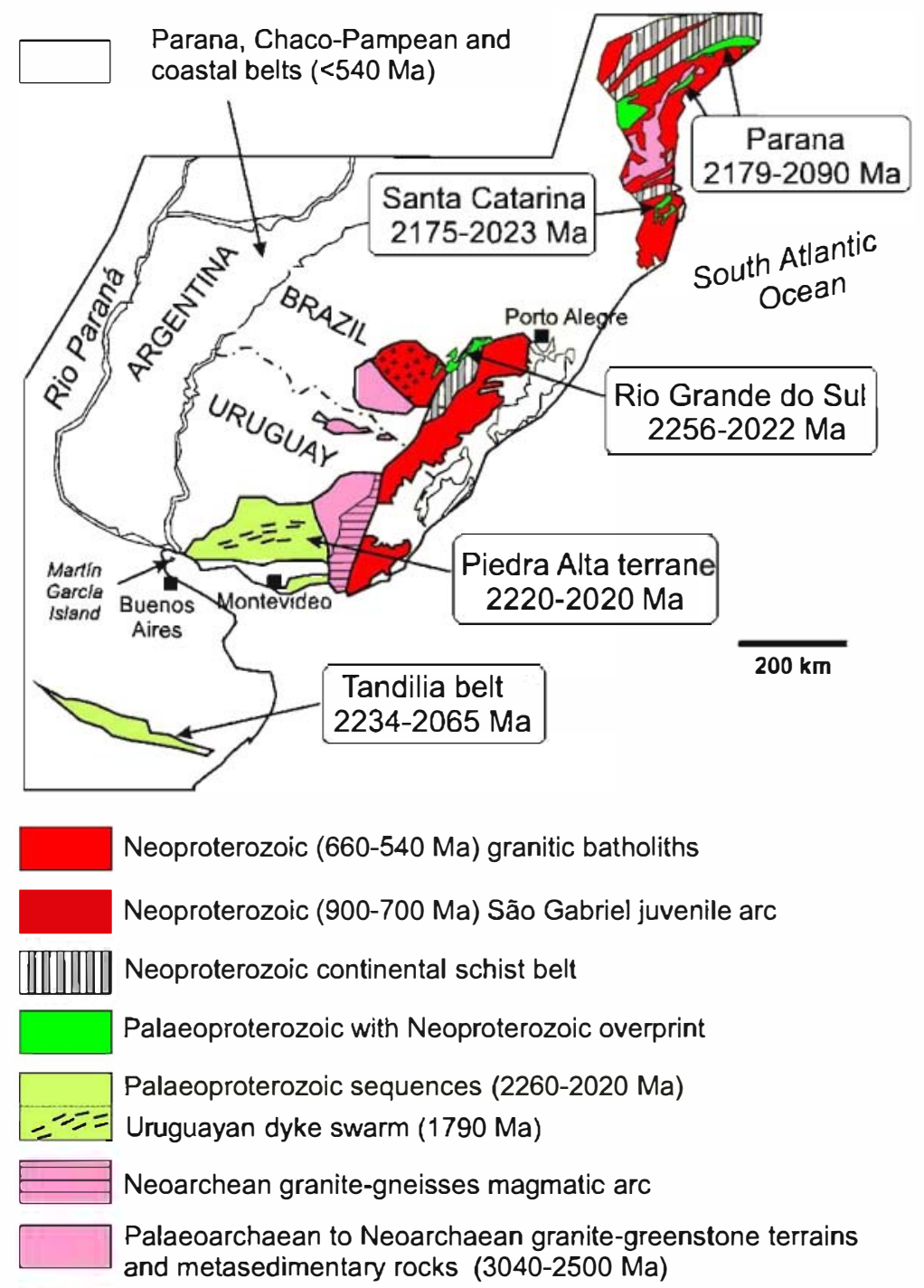

Fig. 4. Schematic geological map of the Atlantic region in southern Brazil, Uruguay and east-central Argentina displaying the Precambrian basement units (modified from Santos et al., 2003; Gastal et al., 2005). U-Pb ages for Proterozoic units are from Santos et al. (2003) (southern Brazil), Peel and Preciozzi (2006) (Piedra Alta terrane, Uruguay), and from Hartmann et al. (2002b) and Cingolani et al. (2005) (Tandilia belt, Argentina).

(Kröner and Cordani, 2003; Mantovani and Brito Neves, 2005 and references therein). Neoproterozoic (Brasiliano) belts have not been observed or detected geophysically within the egg-shaped inferred limits of the craton discussed below.

The boundary contacts of the RPC (Table 2) are only exposed in southern Uruguay, where the Mesoproterozoic to Neoproterozoic Cuchilla Dionisio terrane was emplaced against the Archaean to Palaeoproterozoic Nico Pérez terrane by sinistral lateral accretion along the Sierra Ballena Shear Zone at about $530 \mathrm{Ma}$ (Bossi and Gaucher, 2004) (Fig. 2). The Cuchilla Dionisio terrane, composed of metamorphic basement $(1006 \pm 37 \mathrm{Ma}, \mathrm{U}-$ $\mathrm{Pb}$, Preciozzi et al., 1999) intruded by syn-collisional to late-collisional 680 to $550 \mathrm{Ma}$ granites, extends to southern Brazil (Pelotas region, Bossi and Gaucher, 2004 and references therein). The Late Neoproterozoic to Early Cambrian components of this area are usually referred to as the Dom Feliciano orogenic belt - see Basei et al. (2000) and Bossi and Gaucher (2004) for a review of nomenclature. This eastern limit can be extrapolated southwards to the eastemmost tip of the Tandilia belt, where low-grade metapelites found in the Punta Mogotes borehole have $\mathrm{K}-\mathrm{Ar}$ ages of 576 to $615 \mathrm{Ma}$ and have been correlated with similar rocks in the Cuchilla Dionisio terrane in Unuguay (Cingolani and Bonhomme, 1982; Dalla Salda et al., 1988) (Figs. 2 and 3a). Farther south, the basement of the Palaeozoic Sierra 
de la Ventana Fold Belt is composed of $607 \pm 5 \mathrm{Ma}$ Brasiliano collisional granites intruded by $531-524 \mathrm{Ma}$ A-type granites, and $509 \pm 5 \mathrm{Ma}$ peralkaline rhyolites (U-Pb SHRIMP, Rapela et al., 2003). This indicates that the RPC does not continue below the Sierra de la Ventana fold belt, and its southern limit probably swings to the WNW, sub-parallel to the strike of the Tandilia belt (Fig. 2).

To the northwest of the Tandilia belt the craton is covered by the Palaeozoic-Mesozoic Chacoparanense basin and Cenozoic sediments, and its limits towards the Eastern Sierras Pampeanas can only be inferred from geophysical studies and boreholes drilled for oil exploration. Seismic reflexion cross-sections and boreholes at $34^{\circ} \mathrm{S}, 64^{\circ} \mathrm{W}$ indicate that the faulted margin of a deep Early Cretaceous rift basin probably reflects the Early Palaeozoic boundary of the RPC with the Sierras

Table 1

Main geological units of the Río de la Plata craton and overlying Neoproterozoic and Early Palaeozoic platforms

\begin{tabular}{ll}
\hline Block/belt/terrane & Age/lithology \\
\hline 1) Tandilia belt & \\
Balcarce Formation: & $\begin{array}{l}<480 \mathrm{Ma} \text { (Silurian?), quartzite-dominated } \\
\text { siliciclastic succession. } \\
\text { Sierras Bayas Group }\end{array}$ \\
$\begin{array}{l}\text { Neoproterozoic, } 350 \mathrm{~m} \text { thick carbonate- } \\
\text { siliciclastic succession. }\end{array}$ \\
Basement complex & $\begin{array}{l}2.26-2.07 \mathrm{Ga} \text { tonalitic to granitic gneisses, } \\
\text { amphibolites and migmatites. Thick mylonite } \\
\text { belts. } 1.59 \mathrm{Ga} \text { tholeiitic dyke swarm. }\end{array}$
\end{tabular}

2) Piedra Alta terrane

Basement complex: $2.22-2.02 \mathrm{Ga}$, abundant tonalites, metavolcanic and metasedimentary belts injected by voluminous $\mathrm{K}$-rich granites. $1.79 \mathrm{Ga}$ tholeiitic dyke swarm.

\section{3) Nico Pérez terrane \\ Arroyo del Soldado Group:}

Basement complex:

\section{and siliciclastic rocks.}

alternation of carbonates

\subsection{1-3.10 Ga greenstone belt}

(ultramafic schists, amphibolite and tonalites), with a 3.3-2.76 Ga platform cover (marbles, quartz, metapelites); 2.6-2.0 Ga felsic meta-trondhjemites and granulites.

4) Tacuarembó block

Basement complex:

2.55-2.51 Ga meta-trondhjemites and mafic garnet granulites, metamorphosed at $2.03-2.02 \mathrm{Ga}$.

\section{5) Asunción Arch}

Basement complex:
Table 2

Pre-Silurian terranes and belts surrounding the Río de la Plata craton

\begin{tabular}{ll}
\hline Belt/terrane & Age/lithology \\
\hline 1) Eastern boundary: the Cuchilla Dionisio terrane \\
Rocha Group: & $0.60-0.55$ Ga siliciclastic \\
& succession of chlorite phyllite, \\
graphitic phyllite and meta-arenite. & $0.64-0.59$ Ga volcanic arc and \\
Neoproterozoic batholiths: & syn-collisional granites; \\
& $0.55-0.538$ post-orogenic \\
& alkaline granites. \\
Basement complex: & $1.0-0.9$ granitic orthogneisses \\
& and migmatites.
\end{tabular}

2) Southern boundary: the Sierra de la Ventana Fold Belt Basement complex: $\quad 0.607 \mathrm{Ga}$ granitic paragneisses intruded by A-type $(0.53 \mathrm{Ga})$ and I-type $(0.524 \mathrm{Ga})$ granites; $0.509 \mathrm{Ga}$ peralkaline rhyolites.

3) Western, proto-Pacific boundary

(a) Eastern Sierras Pampeanas, Pampean belt

Northern sector Upper Vendian-Early Lower

(Puncoviscana Formation): Cambrian thick sequences of folded low-grade metapelites and metaturbidites. Restricted alkaline lava, sills and dykes. Intrusion of $0.536-0520 \mathrm{Ga}$ peraluminous and calc-alkaline granites.

Southern Sector (Sierras de Córdoba, Ancasti):

Medium to high grade equivalents of the Puncoviscana formation: banded schists, gneisses and migmatites; $0.54-0.53$ Ga calcalkaline granites; 0.52 migmatites and S-type granites.

(b) Eastern Sierras

Pampeanas, Famatinian belt

Widespread 500-463 Ma magmatism: I- and S-type granites, minor TTG suites; coeval volcanism. Latest Cambrian to Llanvirn epiclastic deposits, interbedded with volcaniclastic and shallow marine siltstones. Equivalent medium-to-high grade rocks.

(c) Western Sierras Pampeanas - 1200-1000 Ma scattered basement blocks west of the Famatinian belt, from $29^{\circ}$ to $36^{\circ} 46^{\prime \prime} \mathrm{S}$. Basic to ultrabasic igneous complexes, trondhjemite plutons and siliciclastic and calc-silicate metasedimentary sequences. Neoproterozoic calcsilicate metasedimentary platform. Strong Ordovician overprint in some sectors.

Pampeanas (Webster et al., 2004) (Fig. 2). Magnetotelluric studies indicate that the western limit between the RPC and the Early Palaeozoic basement of the
$2.02 \mathrm{Ga}$ orthogneisses, banded granulites, amphibolites and quartzites, rejuvenated at $0.620-0.61$ and $0.55-0.50 \mathrm{Ga}$. 
Pampean belt of the Eastern Sierras Pampeanas is remarkably sharp (Booker et al., 2004; López de Luchi et al., 2005). This limit is most probably also a complex faulted margin reactivated by Early Cretaceous normal faulting during the opening of the South Atlantic (Webster et al., 2004) and the subsequent reverse faulting that raised the Sierras de Córdoba over the Pacific flat-subduction zone in Miocene times (Ramos et al., 2002). The only likely evidence of the original characteristics of this contact is ductile F2 dextral shearing observed in the easternmost sector of the Pampean belt (von Gosen and Prozzi, 2005). Here, NNE-trending dextral mylonite belts of inferred Early Cambrian age (Martino, 2003) are related to a magmatic arc (Lira et al., 1997; Rapela et al., 1998). An interval of 528-538 Ma can be inferred for this deformation from U-Pb SHRIMP dating of granites variously affected by and intruding the mylonites at $30^{\circ} 41^{\prime} \mathrm{S}, 64^{\circ} 19^{\prime} \mathrm{W}$ (our unpublished data with $\mathrm{N}$. Iannizzotto).

In the northwest (Fig. 2), the limit of the RPC is thought to follow the NE-SW main fault bounding the Early Palaeozoic subsurface Las Breñas basin (Fernández Garrasino et al., 2005 and references therein), whereas the northern limit lies to the north of high-grade Palaeoproterozoic rocks in the Asunción Arch of Paraguay (Cordani et al., 2001). The northeastern limit is equated with the boundary fault between the Tacuarembó and the 900-700 Ma São Gabriel arc (Kröner and Cordani, 2003; Saalman et al., 2006).

\subsection{Geochronology of the Río de la Plata craton}

In southern Uruguay three discrete terranes have been recognized within the RPC (Table 1), separated by strike-slip faults that developed $6-8 \mathrm{~km}$ thick mylonite zones (Figs. 2 and 3a). The Nico Pérez terrane is separated from the Piedra Alta terrane and the Pando belt by the N-S dextral Sarandí del Yí megashear (Bossi and Campal, 1992; Bossi et al., 2005). The Pando belt, separated from the Piedra Alta terrane by the E-W Colonia sinistral shear zone (Fig. 3a) has been correlated with the Tandilia belt in Argentina, jointly defining a Tandilia terrane according to Bossi et al. (2005). This is consistent with palaeomagnetic studies suggesting that both sectors were part of a single continental block at $550 \mathrm{Ma}$ (Rapalini, 2005, 2006). The Piedra Alta terrane in Uruguay is composed of magmatic rocks of various compositions that show a range of $\mathrm{U}-\mathrm{Pb}$ ages between 2.22 and $2.02 \mathrm{Ga}$ (Hartmann et al., 2000, 2002a; Santos et al., 2003; see also Peel and Preciozzi, 2006 for further references). The Tandilia belt (Dalla Salda et al., 2005 and references therein) includes the southemmost exposures of the RPC (Fig. 2) and consists of tonalitic to granitic gneisses, amphibolites and migmatites, all affected by thick mylonite belts; rare schists, marbles and metavolcanic rocks are also present. U-Pb SHRIMP data obtained for tonalites, trondhjemites, granites, and charnockitic gneisses from classic localities provide a range of ages between 2.26 and $2.07 \mathrm{Ga}$ (Hartmann et al., 2002b; Cingolani et al., 2005). Calc-alkaline dykes in Tandil are coeval $(2020 \pm 24,2007 \pm 24 \mathrm{Ma})$ with the youngest granites of the belt and are considered to represent a transtensional stage of the Transamazonian orogeny (Iac mín et al., 2001; Teixeira et al., 2002). In the Pando belt of Unuguay (Santos et al., 2003), gneisses $(2.17 \mathrm{Ga})$ and charnockites $(2.06 \mathrm{Ga})$ fall in the same age range as those of the Tandilia belt. Swarms of tholeiitic dykes intruded into both the Tandilia belt $(1.59 \mathrm{Ga})$ and the Piedra Alta terrane (1.79 Ga, Fig. 4) have been associated with extensional tectonic stages $200-400 \mathrm{Ma}$ after the Transamazonian orogeny (Hall et al., 2001; Iacumín et al., 2001; Teixeira et al., 2002).

The oldest rocks in the RPC have been identified in the southern part of the Nico Pérez terrane, where a 3.41-3.10 Ga Archaean greenstone belt and its deformed sedimentary cover of marbles, quartzites and metapelites were thrust-stacked at $2.7 \mathrm{Ga}$ (Hartmann et al., 2001). Palaeoproterozoic granulites dominate the northern sector $(2.06 \mathrm{Ga})$, while meta-trondhjemites formed at $2.15 \mathrm{Ga}$ and metamorphosed at $2.08 \mathrm{Ga}$ appear in the Rivera block, which is considered part of the Nico Pérez terrane (Fig. 2) (Santos et al., 2003). Neoarchaean rocks - meta-trondhjemites and mafic gamet granulites of $2.55-2.51 \mathrm{Ga}$ metamorphosed at 2.03$2.02 \mathrm{Ga}$ have been also described from the Tacuarembó block (Fig. 2) (Hartmann et al., 1999). Finally, in the southern sector of the "Asunción arch", U-Pb SHRIMP ages and $\mathrm{Rb}-\mathrm{Sr}$ and $\mathrm{Sm}-\mathrm{Nd}$ measurements obtained in a basement composed of orthogneisses, banded granulites, amphibolites and quartzites indicate that this is a $2.02 \mathrm{Ga}$ basement rejuvenated in two distinct tectonothermal events, at $620-610 \mathrm{Ma}$ and $550-500 \mathrm{Ma}$ (Cordani et al., 2001) (Fig. 2).

The most significant evolutionary characteristics of the RPC are: (i) a lithology dominated by juvenile Palaeoproterozoic rocks of the Transamazonian cycle, with $\mathrm{Nd}$ model ages of 2.0-2.7 Ga and a Sm-Nd isochron age of $2140 \pm 88$ Ma (Preciozzi et al., 1999; Pankhurst et al., 2003) and (ii) the lack of any major Mesoproterozoic or younger event, except for the tholeiitic dyke swarms. However, it is worth noting that the age pattems of the different terranes and blocks of the RPC are also present in other Archaean/Palaeoproterozoic blocks and microplates 
of southern Brazil, such as those in the Santa Catarina and Paraná areas (Fig. 4), but that $\mathrm{U}-\mathrm{Pb}$ ages younger than $2.0 \mathrm{Ga}$ have not yet been found in any Transamazonian terrane in Brazil (Santos et al., 2003). The tectonic activity in these southern Transamazonian blocks has been associated with the 2.25-2.12 Ga accretionary Encantadas orogeny, and a $2.10-2.08$ Ga collisional overprint, the Camboriú orogeny (Hartmann et al., 2002b).

\subsection{Platform sequences of the Rio de la Plata craton}

The RPC is covered by Neoproterozoic and Early Palaeozoic platform sequences (Table 1), the former being particularly conspicuous in the Nico Pérez terrane and in the Tandilia belt. The Arroyo del Soldado Group in Uruguay (Fig. 3a) is a $5 \mathrm{~km}$ thick succession, characterized by altemation of carbonates and siliciclastic rocks, in which fossils and chemostratigraphic studies indicate a Vendian to Lower Cambrian age (Gaucher et al., 2004, 2005 and references therein). ${ }^{87} \mathrm{Sr} /{ }^{86} \mathrm{Sr}$ and $\delta^{13} \mathrm{C}$ variations suggest that sedimentation started at about $580 \mathrm{Ma}$ and culminated at about $530 \mathrm{Ma}$ (Gaucher et al., 2004). South of the Colonia shear zone, preliminary C- and O-isotope analyses of limestones that occur at the top of the Piedra de Afilar siliciclastic formation suggest a Cryogenian to Ediacaran age (Pamoukaghlian et al., 2006).

In the Tandilia belt (Fig. 3b), the Neoproterozoic carbonate-siliciclastic succession represented by the Sierras Bayas Group and the Cerro Negro Formation is comparatively thinner (350 m) (Poiré and Spalletti, 2005 and references therein). Recent litho-, bio- and chemostratigraphical correlations between the Arroyo del Soldado Group and the Sierras Bayas Group/Cerro Negro Formation, suggest that these units formed an extensive marine shelf of late Ediacaran age developed over a large part of the RPC, possibly under tropical climate conditions (Gaucher et al., 2005; Gómez Peral et al., 2007). In the Tandilia belt, there is also a siliciclastic succession, the Balcarce Formation (Fig. 3b), dominated by quartzites with minor pelitic intercalations that cany abundant trace fossils indicating an Early Palaeozoic age (Cambrian?-Ordovician?) (Poiré et al., 2003; Poiré and Spalletti, 2005). The recognition of thick progradational clinoforms indicates that the Balcarce sea was open to the south, as has also been inferred from coast-subparallel, west-directed palaeocurrents (Teruggi, 1964; Dalla Salda and Iñiguez, 1979; Poiré et al., 2003) (Fig. 3b).

Provenance studies in the $600-550$ Ma siliciclastic Rocha Group in the Cuchilla Dionisio terrane (Fig. 3a) indicate a close correlation with the Oranjemund Group of the Gariep basin in southwestern Africa, with an inferred back-arc setting (Basei et al., 2005). Closure of the Adamastor ocean formed a huge 640-590 volcanic arc and would have juxtaposed the RPC and the Kalahari cratons, the suture between them being the crustal-scale Sierra Ballena Shear Zone (Basei et al., 2005, Fig. 3a).

\subsection{The proto-Andean Palaeozoic and Mesoproterozoic belts}

Adjacent to the western edge of the RPC, the Eastem Sierras Pampeanas (Fig. 5) are uplifted basement blocks produced by Miocene-Recent flat-slab subduction in the $27^{\circ}-33^{\circ} 30^{\prime} \mathrm{S}$ Andean segment (Ramos et al., 2002). The eastern sector of this province, known as the Pampean belt, is characterized by Late Neoproterozoic sedimentation and Cambrian deformation, magmatism and metamorphism. The western sector, the Famatinian belt, is characterized by Upper Cambrian to Middle Ordovician marine sedimentation and conspicuous Early Ordovician magmatism (Rapela, 2000). Ordovician magmatism also affected the Pampean belt (Pankhurst et al., 2000) and the Western Sierras Pampeanas (Baldo et al., 2005), and in the latter Ordovician metamorphism overprinted a Grenville-age basement (Casquet et al., 2001).

From $22^{\circ} \mathrm{S}$ to $27^{\circ} \mathrm{S}$ the Pampean belt is dominated by the Puncoviscana Formation (Table 2), composed of thick sequences of low-grade metamorphic rocks including metapelites and metaturbidite beds with wellpreserved primary structures that indicate an east to west-northwest pattern of sediment transport (Ježek, 1990). Trace fossils suggest an Ediacaran to Early Lower Cambrian age (Aceñolaza and Aceñolaza 2005). Alkaline lava flows, sills and dykes in the lower part of the section show "oceanic island" to "within-plate" signature (Coira et al., 1990), while rift-related alkaline to transitional alkaline to MORB-like basalts appear higher in the section (Omarini et al., 1999). The whole succession is tightly folded and intruded by Cambrian granites, and is unconformably overlain by the late Early Cambrian to Middle Cambrian siliciclastic sediments of the Mesón Group (see Mángano and Buatois, 2004; Aceñolaza and Aceñolaza, 2005 for detailed references). A supracrustal source (or sources) has been inferred for the entire basin (Zimmermann, 2005).

From $27^{\circ}$ to $33^{\circ} \mathrm{S}$ only metamorphic equivalents of the Puncoviscana Formation are exposed, e.g. in the Sierra de Córdoba and the Sierra de Ancasti (Fig. 5). There is a continuous variation from unmetamorphosed turbiditic rocks in the north, through weakly foliated pelites, to schists with well-developed pressure solution 


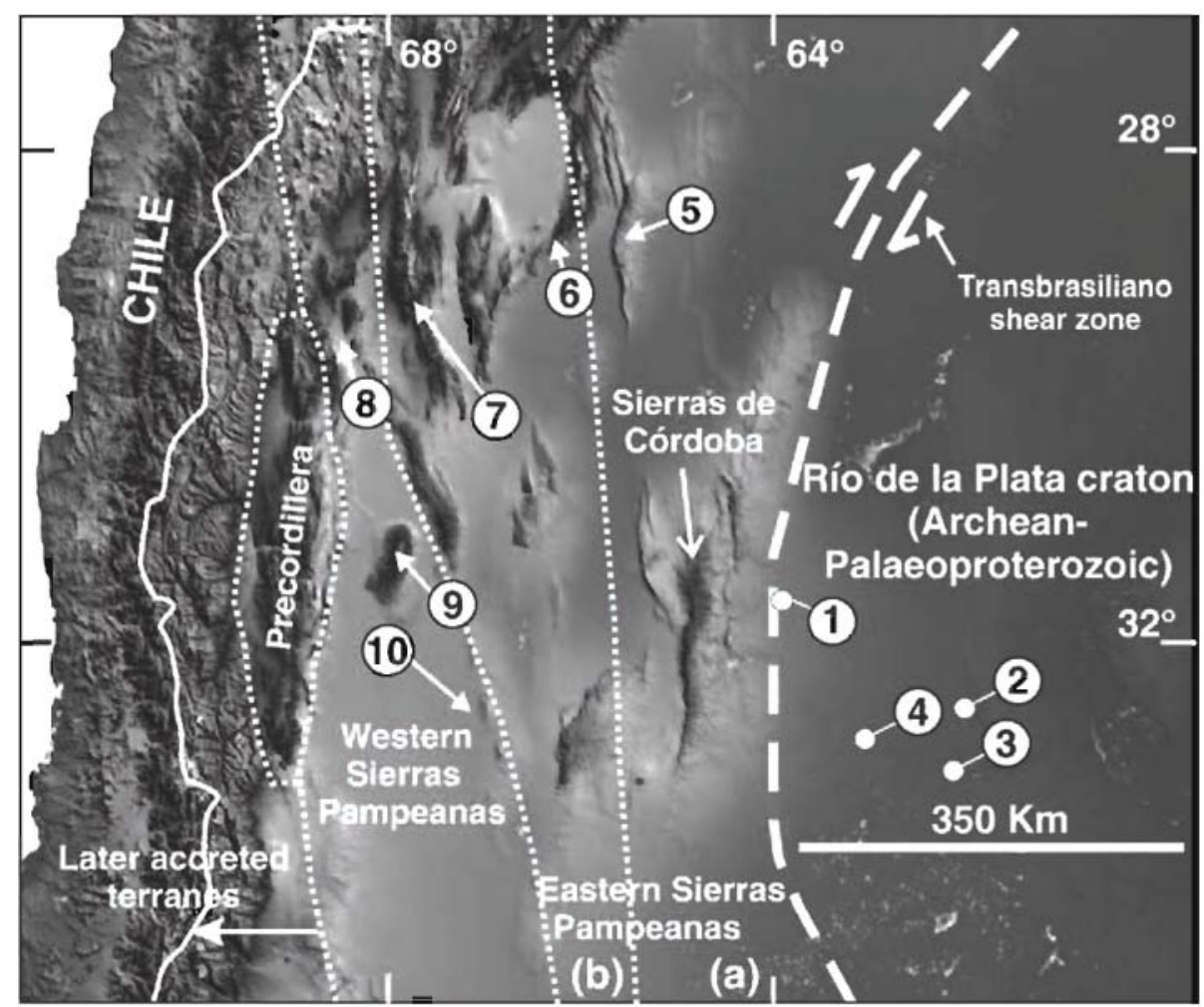

Fig. 5. Digital image of central-west Argentina and central Chile showing the inferred western limit of the Río de la Plata craton, the proto-Andean belts and sampling localities. Boreholes in the Chacoparanense basin: (1) Santiago Temple, (2) Saira, (3) Camilo Aldao, (4) Ordoñez. Pampean belt: (5) Sierra de Ancasti, Famatinian belt: (6) La Cébila Formation, (7) Famatina Basin, Suri Formation. Western Sierras Pampeanas: (8) Sierras de Umango, Maz and Espinal, (9) Sierra de Pie de Palo, (10) Sierra de El Gigante.

cleavage, and finally to compositionally-banded schists and gneisses (Piñán-Llamas and Simpson, 2006). A 540-530 Ma Late Precambrian to Early Cambrian volcanic arc and a Cambrian low- to high-grade metamorphic sequence intruded by S-type anatectic granites at $520 \mathrm{Ma}$, make up most of the southem part of the Pampean belt (Lira et al., 1997; Rapela et al., 1998, 2002). Ophiolitic remnants ascribed to a back-arc basin have also been described (Escayola et al., 1996) and assigned a late Neoproterozoic age of ca. $625 \mathrm{Ma}$ on the basis of Sm-Nd data (Escayola et al., 2005). Several tectonic models have been proposed for Pampean sedimentation, including (A) a Neoproterozoic passive margin developed in the western margin of the RPC (e.g. Cøira et al., 1982; Ježek et al., 1985; Kraemer et al., 1995; Rapela et al., 1998; Piñán-Llamas and Simpson, 2006), (B) deposition in a fore-arc or foreland basin during the Pampean orogeny (e.g. Keppie and Bahlburg, 1999; Schwartz and Gromet, 2004; Zimmermann, 2005) and (C) development at the margin of or within back-arc basins of terranes located outboard of the Gondwana margin, with which they subsequently collided (e.g.
Ramos, 1988; Escayola et al., 2005). Identification of the arc source of the Neoproterozoic zircons is a significant problem for all these models.

The Famatinian belt (Table 2) consists of widespread 500-463 Ma (Early and Middle Ordovician) arc-related magmatic rocks (the Famatinian magmatism), latest Cambrian to Darriwilian sedimentary rocks of the Famatina basin, and low- to high-grade metamorphic rocks (Pankhurst et al., 2000; Astini, 2003; Dahlquist et al., 2005). A distinctive characteristic of the Sierra de Famatina is Lower- to Middle Ordovician epiclastic deposits interbedded with volcaniclastic, volcanogenic and volcanic rocks, together with intervals of fossiliferous siltstones with shallow marine fauna such as brachiopods, trilobites and conodonts (Astini, 2003 and references therein). Recently-found well-preserved Lower Ordovician fossils in amphibolite-grade metasedimentary rocks in the eastem part of the Famatinian belt (La Cébila area, Fig. 5) suggest extensive development of the original Ordovician basin (Verdecchia et al., 2007).

Basement blocks located to the west of the Famatinian belt, known as the Westem Sierras Pampeanas, 
such as the sierras of Pie de Palo, Maz, Espinal and Umango (Fig. 5) are characterized by abundant basic and ultrabasic rocks, calc-silicate sequences and volumetrically small and scarce granitic bodies, and were recognized as lithologically distinct from the Eastern Sierras Pampeanas (Caminos, 1979). Mesoproterozoic igneous rocks that were contemporaneous with the Grenville orogeny of eastern and northeastern North America ( 1.0-1.2 Ga) have been reported in the Sierra de Pie de Palo (Fig. 1, McDonough et al., 1993; Pankhurst and Rapela, 1998; Vujovich et al., 2004). U-Pb, $\mathrm{Sm}-\mathrm{Nd}$ and $\mathrm{Rb}-\mathrm{Sr}$ Mesoproterozoic ages have also been reported in the Sierra de Umango (Varela et al., 2004), Sierra de Maz (Casquet et al., 2005a), Ponon Trehue (Cingolani and Varela, 1999), and as far south as Las Matras block at $36^{\circ} \mathrm{S}, 67^{\circ} \mathrm{W}$, where an undeformed $1.2 \mathrm{Ga}$ tonalite-trondhjemite pluton has been described (Sato et al., 2000). These Mesoproterozoic rocks have been considered to be the eastemmost exposures of the basement to the Precordillera terrane, a supposed Laurentian continental block accreted to Gondwana during the Famatinian orogeny (Astini et al., 1995; Thomas and Astini, 2003, and references therein) and equivalent to the Cuyania terrane of Ramos et al. (1998). However, the boundaries of the Mesoproterozoic Western Sierras Pampeanas belt are still poorly defined, and its alleged allochthoneity has been challenged (Galindo et al., 2004). Furthermore, the similarities between the Arequipa craton and the Western Sierras Pampeanas, including the existence of Grenvillian massif-type anorthosites in both sectors, suggested that these two regions were part of a single continental crustal block from Mesoproterozoic times onwards (Casquet et al., 2005b, 2006). Finally, Ordovician garnet-bearing granites reported intruding the Sierra de Pie de Palo suggest that this sierra was part of the upper plate during the Famatinian event, and therefore was not part of the basement of the Precordillera terrane (Pankhurst and Rapela, 1998; Baldo et al., 2005).

\section{Borehole stratigraphy of the Chacoparanense basin}

With the outcrops of the RPC restricted to the Atlantic margin, more than $80 \%$ of the postulated extension of the craton is covered by Phanerozoic sediments of the Chacoparanense basin. Geophysics and boreholes sunk for oil exploration show that the oldest components of the basin are generally Upper Palaeozoic sedimentary rocks. Additionally, Lower Palaeozoic sediments are found in the northwestern corner (Las Breñas basin, Fig. 2; Russo et al., 1979; Fernández Garrasino et al., 2005), underlying well-known Silurian iron-rich levels. A Cambrian to Ordovician age has thus been assigned to this $5000 \mathrm{~m}$ thick depocentre, which started with marine quartzites and intercalated grey slates that have been correlated with the Cambrian Mesón Group (A. Mingramm in Russo et al., 1979, and references therein).

The only direct evidence for the composition and age of the basement to the basin comes from samples of magmatic and metamorphic rock recovered from the bottom of four deep boreholes in the central-western part of the craton (Figs. 2, 5) (Russo et al., 1979). As shown in the stratigraphic columns constructed from these boreholes, basement was reached at 1046-3340 m below surface (Fig. 6). In all cases Late Palaeozoic successions dominated by Upper Carboniferous to Lower Permian diamictites rest unconformably on the basement, reaching a thickness of $2200 \mathrm{~m}$ in the Ordoñez borehole (Russo et al., 1979; Winn and Steinmetz, 1998). Three $\mathrm{K}-\mathrm{Ar}$ ages have previously been reported for basement samples: $787 \pm 100 \mathrm{Ma}$ (Santiago Temple olivine gabbro), $441 \pm 10 \mathrm{Ma}$ (Ordoñez granite) and $1516 \pm 150 \mathrm{Ma}$ (Saira diorite) (Russo et al., 1979), suggesting Meso- to Neoproterozoic and Ordovician cooling ages. If these ages were correct, they would indicate a completely distinctive age pattern for this sector and would suggest that the limit with the Palaeoproterozoic/Archaean terranes should be placed farther east (e.g. Ramos, 1995; Keppie and Bahlburg, 1999; Leal et al., 2003). However, our results revise significantly the age of the basement and do not support the idea of Mesoproterozoic substrata.

\section{Petrography and geochemistry of borehole samples}

\subsection{Mineralogy}

Santiago Temple borehole $\left(31^{\circ} 23^{\prime} S, 63^{\circ} 26^{\prime} \mathrm{W}\right)$. The sample is a banded olivine gabbro-norite that underwent localized subsolidus alteration during at least one metamorphic event. The igneous association consists of undeformed clinopyroxene (diopside-augite), minor othopyroxene $\left(\mathrm{En}_{77}\right)$, olivine $\left(\mathrm{Fo}_{76-77}\right)$, plagioclase $\left(\mathrm{An}_{85-93}\right)$ and phlogopite. Subsolidus alteration is represented by progressively lower-temperature interaction between minerals and mainly aqueous fluids. Recorded zoning consists of: (A) local symplectitic intergrowth of pargasite, spinel $\left(\mathrm{Sp}_{41-52}\right)$ and epidote $\left(\mathrm{Ps}_{29}\right)$ adjacent to plagioclase of the higher-T igneous assemblage, (B) a thin outer lower-temperature zone consisting of hornblende (low-Al pargasite, pargasitic homblende, tschermakitic homblende and Mg-homblende); homblende can also be found as replacements 


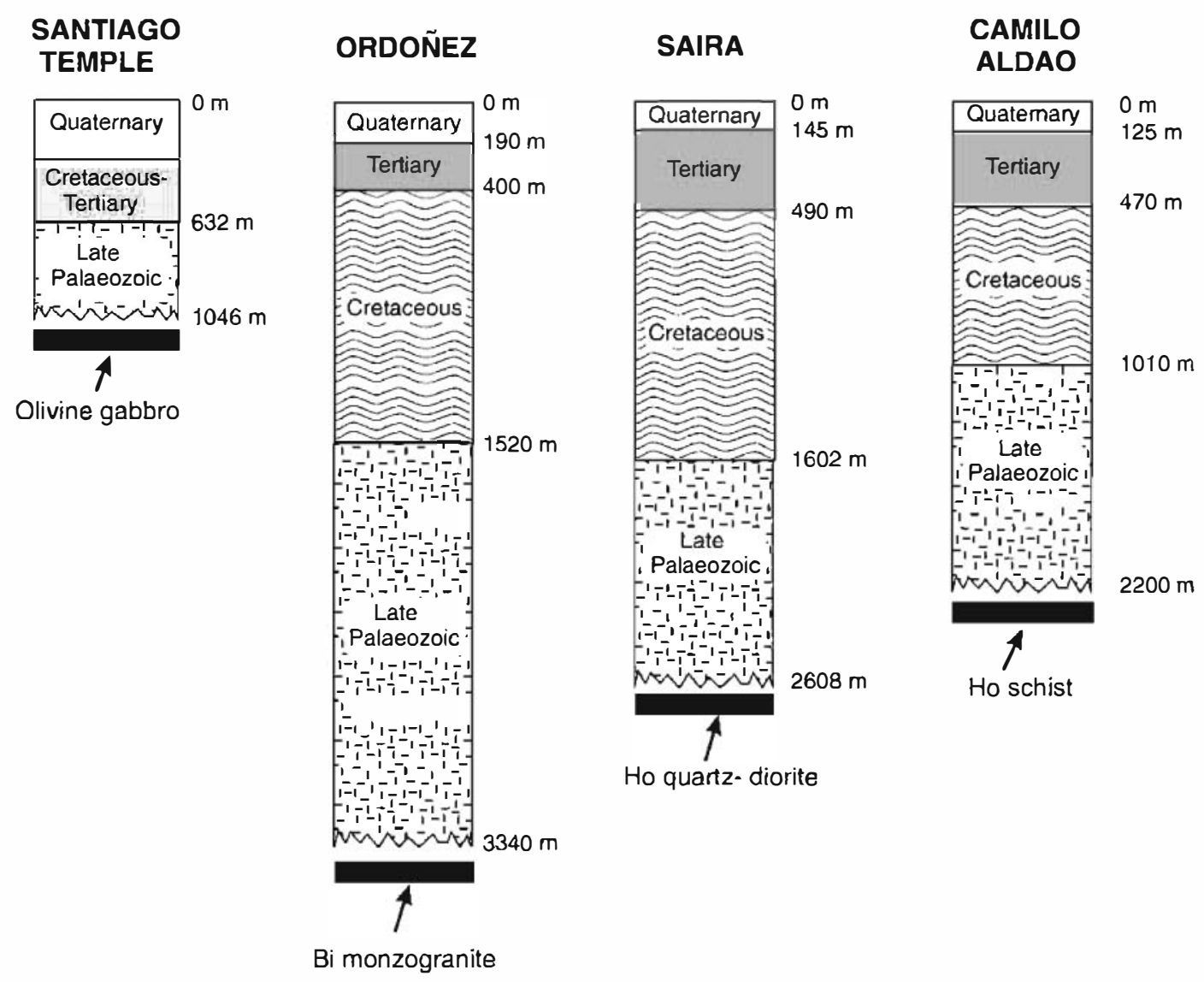

Fig. 6. Stratigraphic columns for boreholes in the Chacoparanense basin (from Russo et al., 1979 and unpublished YPF reports cited by Russo et al., 1979).

along pyroxene-pyroxene and pyroxene-plagioc lase boundaries with no related symplectites, (C) a third zone represented by tremolite-Mg-rich actinolite and haematite. Diablastic growth of $\mathrm{Mg}$-rich chlorite blades took place between zones $\mathrm{A}$ and $\mathrm{B}$, and plagioclase is partially converted into muscovite-sericite and clinozoisite close to the mafic alteration zones. Zone A probably resulted from reaction between primary mafic minerals and an aqueous fluid under upper amphibolite or granulite facies conditions. In a $\mathrm{SiO}_{2}-$ $\mathrm{Al}_{2} \mathrm{O}_{3}-\mathrm{CaO}-(\mathrm{Fe}, \mathrm{Mg}) \mathrm{O}$ projection, the compositional plane pargasite + epidote + spinel, intersects the compositional volume olivine + clinopyroxene + orthopyroxene + plagioclase, suggesting that the symplectite arose by an oxidizing reaction of the type (abbreviations after Kretz, 1983):

$\mathrm{Ol}+\mathrm{Cpx}+\mathrm{Opx}+\mathrm{Pl}+\mathrm{H}_{2} \mathrm{O}+\mathrm{O}_{2}=\mathrm{Hb}+\mathrm{Sp}+\mathrm{Ep}$

Oxidizing conditions persisted during formation of zone $\mathrm{C}$, as evidenced by the formation of haematite, suggesting that the three zones resulted from a unique oxidizing hydrothermal event. Subsolidus formation in the corona assemblage of $\mathrm{OH}$-bearing minerals such as amphibole, epidote and chlorite at the expense of anhydrous igneous minerals implies the participation of a mainly aqueous fluid such as water, which could not be derived from the primary igneous assemblage. This statement is particularly true in the case of epidote, which requires values of $X_{\mathrm{H}_{2} \mathrm{O}}$ close to unity. A final hydrothermal event is represented by microfracture fillings of calcite and serpentine minerals.

Hornblende-spinel symplectites have been described from granulite facies meta-gabbros and meta-troctolites (e.g., Lang et al., 2004 and references therein). The presence of epidote in the Santiago Temple meta-gabbro remains puzzling, however. TWQEE (Berman, 1991) computation of equilibrium reactions between amphibole and spinel end-members suggests significant chemical disequilibrium. However, the possibility that symplectitic epidote formed later than homblendespinel symplectite cannot be excluded. 
Table 3

Geochemical and isotope data of borehole samples

\begin{tabular}{|c|c|c|c|c|}
\hline Sample & Santiago Temple & Saira & Camilo Aldao & Ordoñez \\
\hline \multicolumn{5}{|c|}{ Major elements (wt.\%) ${ }^{*}$} \\
\hline $\mathrm{SiO}_{2}$ & 46.44 & 51.03 & 59.92 & 72.53 \\
\hline $\mathrm{TiO}_{2}$ & 0.33 & 1.77 & 0.68 & 0.21 \\
\hline $\mathrm{Al}_{2} \mathrm{O}_{3}$ & 6.45 & 20.44 & 14.21 & 13.88 \\
\hline $\mathrm{Fe}_{2} \mathrm{O}_{3} \mathrm{t}$ & 8.08 & 8.61 & 7.39 & 1.99 \\
\hline $\mathrm{MnO}$ & 0.18 & 0.11 & 0.11 & 0.02 \\
\hline $\mathrm{MgO}$ & 20.22 & 1.39 & 5.69 & 0.39 \\
\hline $\mathrm{CaO}$ & 13.08 & 9.85 & 4.82 & 1.28 \\
\hline $\mathrm{Na}_{2} \mathrm{O}$ & 0.44 & 4.29 & 3.00 & 3.57 \\
\hline $\mathrm{K}_{2} \mathrm{O}$ & 0.22 & 0.37 & 1.10 & 4.91 \\
\hline $\mathrm{P}_{2} \mathrm{O}_{5}$ & 0.01 & 0.18 & 0.13 & 0.03 \\
\hline LOI & 3.32 & 1.77 & 2.76 & 0.84 \\
\hline Total & 98.73 & 99.10 & 99.81 & 99.65 \\
\hline \multicolumn{5}{|c|}{ Trace elements $(p p m)^{*}$} \\
\hline Cs & 0.5 & 0.6 & 0.9 & 1.5 \\
\hline $\mathrm{Rb}$ & 5 & 6 & 27 & 158 \\
\hline $\mathrm{Sr}$ & 81 & 536 & 387 & 196 \\
\hline $\mathrm{Ba}$ & 76 & 172 & 1013 & 1068 \\
\hline $\mathrm{La}$ & 1.83 & 3.01 & 18.7 & 55.1 \\
\hline $\mathrm{Ce}$ & 4.93 & 7.46 & 39.5 & 102 \\
\hline $\operatorname{Pr}$ & 0.81 & 1.18 & 5.02 & 10.6 \\
\hline $\mathrm{Nd}$ & 4.14 & 5.47 & 18.5 & 31.5 \\
\hline $\mathrm{Sm}$ & 1.25 & 1.51 & 3.58 & 4.48 \\
\hline $\mathrm{Eu}$ & 0.44 & 1.47 & 1.02 & 0.63 \\
\hline Gd & 1.64 & 1.98 & 3.5 & 2.33 \\
\hline $\mathrm{Tb}$ & 0.29 & 0.34 & 0.58 & 0.27 \\
\hline Dy & 1.72 & 2.08 & 3.32 & 1.08 \\
\hline Ho & 0.34 & 0.43 & 0.66 & 0.19 \\
\hline $\mathrm{Er}$ & 0.96 & 1.27 & 1.92 & 0.57 \\
\hline $\mathrm{Tm}$ & 0.13 & 0.19 & 0.29 & 0.09 \\
\hline $\mathrm{Yb}$ & 0.81 & 1.19 & 1.83 & 0.64 \\
\hline $\mathrm{Lu}$ & 0.11 & 0.16 & 0.26 & 0.11 \\
\hline $\mathrm{U}$ & 0.05 & 0.05 & 0.92 & 3.87 \\
\hline Th & 0.2 & 0.18 & 3.1 & 14.6 \\
\hline Y & 10 & 13.2 & 20.5 & 6.8 \\
\hline $\mathrm{Nb}$ & 0.5 & 1 & 5.1 & 3.1 \\
\hline $\mathrm{Zr}$ & 13 & 13 & 119 & 187 \\
\hline Hf & 0.6 & 0.6 & 3.4 & 5.3 \\
\hline $\mathrm{Ta}$ & 0.01 & 0.04 & 0.38 & 0.2 \\
\hline $\mathrm{Sc}$ & 61 & 18 & 20 & 3 \\
\hline $\mathrm{Ga}$ & 6 & 24 & 16 & 17 \\
\hline \multicolumn{5}{|c|}{ Nd isotope data** } \\
\hline $\mathrm{Sm}(\mathrm{ppm})$ & 1.26 & 1.86 & 3.73 & 4.21 \\
\hline Nd (ppm) & 3.88 & 6.8 & 18.89 & 31.33 \\
\hline${ }^{147} \mathrm{Sm} /{ }^{144} \mathrm{Nd}$ & 0.1966 & 0.165 & 0.1193 & 0.0812 \\
\hline${ }^{143} \mathrm{Nd} / /^{144} \mathrm{Nd}$ & 0.512722 & 0.512322 & 0.511645 & 0.511139 \\
\hline$\varepsilon N d t$ & 1.7 & 2.6 & 1.5 & 1.7 \\
\hline$T_{\mathrm{DM}}(\mathrm{Ma})$ & 2327 & 2303 & 2340 & 2312 \\
\hline
\end{tabular}

*Analyses carried out by ACTLABS, Canada.

Major elements determined by ICP spectrometry.

Minor elements determined by ICP-MS spectrometry.

${ }^{* *}$ Analytical methods as in Pankhurst and Rapela (1995):

$\mathrm{Sm}$ and Nd by MS isotope dilution at NIGL $( \pm 0.1 \%, 1 \sigma)$.

${ }^{143} j^{144} \mathrm{Nd}$ measured on MAT $262( \pm 0.005 \%, 1 \sigma)$.

$T_{\mathrm{DM}}$ for crustal sources after $\mathrm{DePaolo}$ et al. (1991). 
Saira borehole $\left(32^{\circ} 30^{\prime} 40^{\prime \prime} S, 62^{\circ} 04^{\prime} 14^{\prime \prime} \mathrm{W}\right)$. The Saira diorite is an Fe-rich rock that shows strong low- to medium-grade alteration. Preserved igneous minerals are homogeneous plagioclase $\left(\mathrm{An}_{47-49}\right)$, probably former pigeonite crystals consisting of clinopyroxene $\left(\mathrm{Wo}_{46-48} \mathrm{En}_{24} \mathrm{Fs}_{28-31}\right)$ lamellae and interleaved alteration products after probable orthopyroxene, and some quartz. Ore minerals (ilmenite and magnetite) and apatite are also considered primary phases. Microfracturing, particularly of plagioclase crystals is the only deformation feature shown by this rock. Microfractures and grain boundaries focused most of the subsolidus fluid-rock alteration. Alteration of mafic minerals produced Fe-rich chlorite $\left(\mathrm{FeO}_{\mathrm{T}}=33.3-35.8\right.$ wt.\%) with $\mathrm{Al}_{2} \mathrm{O}_{3}$ contents between 15.0 and $16.6 \mathrm{wt} . \%$, together with a variety of amphiboles, epidote, calcite and quartz. Plagioclase, however, was replaced only by chlorite richer in $\mathrm{Al}$ and $\mathrm{Fe}$ than the first type $\left(\mathrm{Al}_{2} \mathrm{O}_{3}\right.$ between 19.4 and 20.2 wt.\% and $\mathrm{FeO}_{\mathrm{T}}$ between 36.0 and 38.5 wt.\%). Amphiboles display a wide compositional spectrum. Textural evidence in the form of zonal arrangements suggests that the earlier amphiboles were either $\mathrm{Fe}$-actinolite $\left(\mathrm{Fe}^{*}=\mathrm{Fe} /(\mathrm{Fe}+\mathrm{Mg})=0.58-0.60\right)$ or Fe-rich cummingtonite $\left(\mathrm{Fe}^{*}=0.64-0.68\right)$, the latter as by-products of alteration of probable orthopyroxene lamellae after pigeonite, in association with the Alpoorer chlorite type. Fe-hornblende $\left(\mathrm{Fe}^{*}=0.69-0.70\right)$ developed later and was in tum followed by a distinct stage of blue Fe-tschermakite formation at the rims. Fetschermarkite $\left(\mathrm{Fe}^{*}=0.83-0.88\right)$ is the youngest secondary mineral in the Saira diorite, suggesting that this rock underwent prograde metamorphism from low- to probably medium-grade conditions. The chemical composition of amphiboles evolved accordingly with increasing $\mathrm{Al}$ and $\mathrm{Fe}$ content.

Camilo Aldao borehole $\left(33^{\circ} 07^{\prime} 29^{\prime \prime} S, 62^{\circ} 06^{\prime} 23^{\prime \prime} \mathrm{W}\right)$. The sample is an amphibolitic schist with a basic to intermediate chemical composition (Table 3 ). It shows a

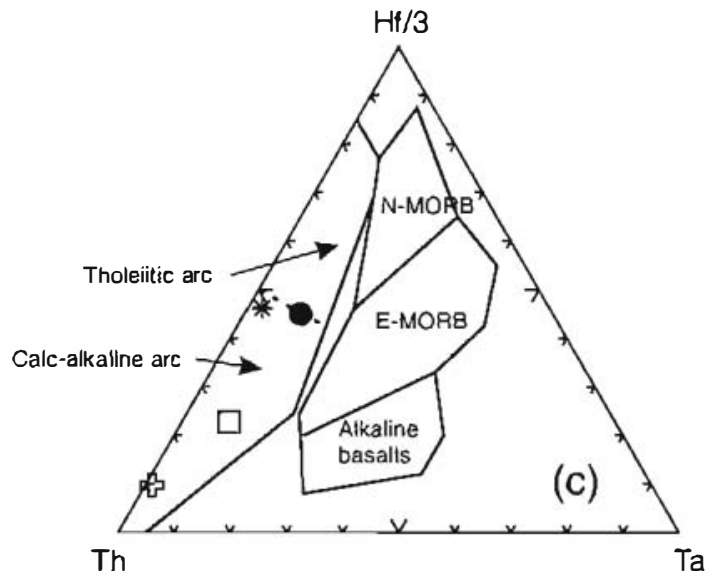

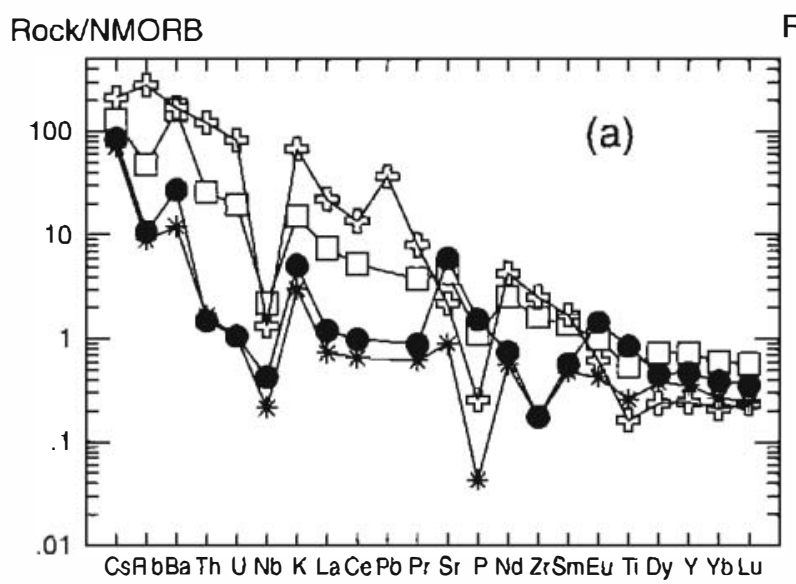

Rock/Chondrites

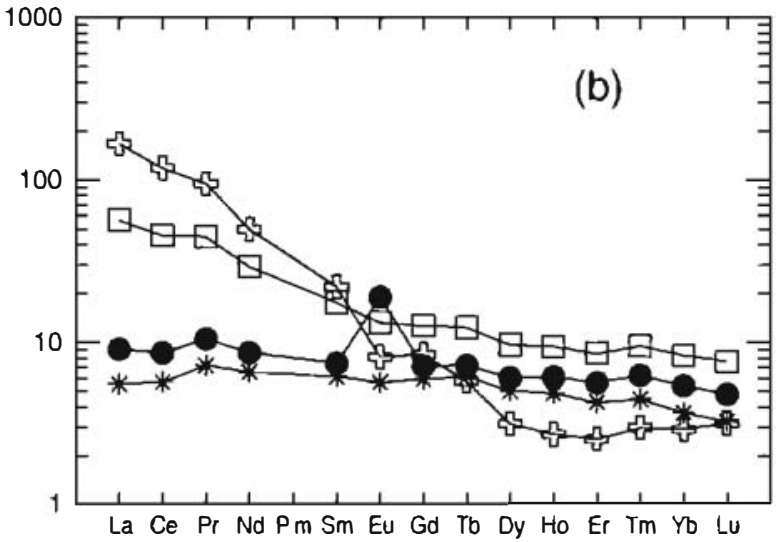

Fig. 7. Geochemical characteristics of borehole samples of the Río de la Plata craton: (a) trace element abundances normalized to N-MORB (Sun and McDonough, 1989), (b) rare earth element diagram normalized to chondrite values (Nakamura, 1974), (c) Th-Hf/3-Ta tectonomagmatic discrimination diagram (Wood, 1980). 

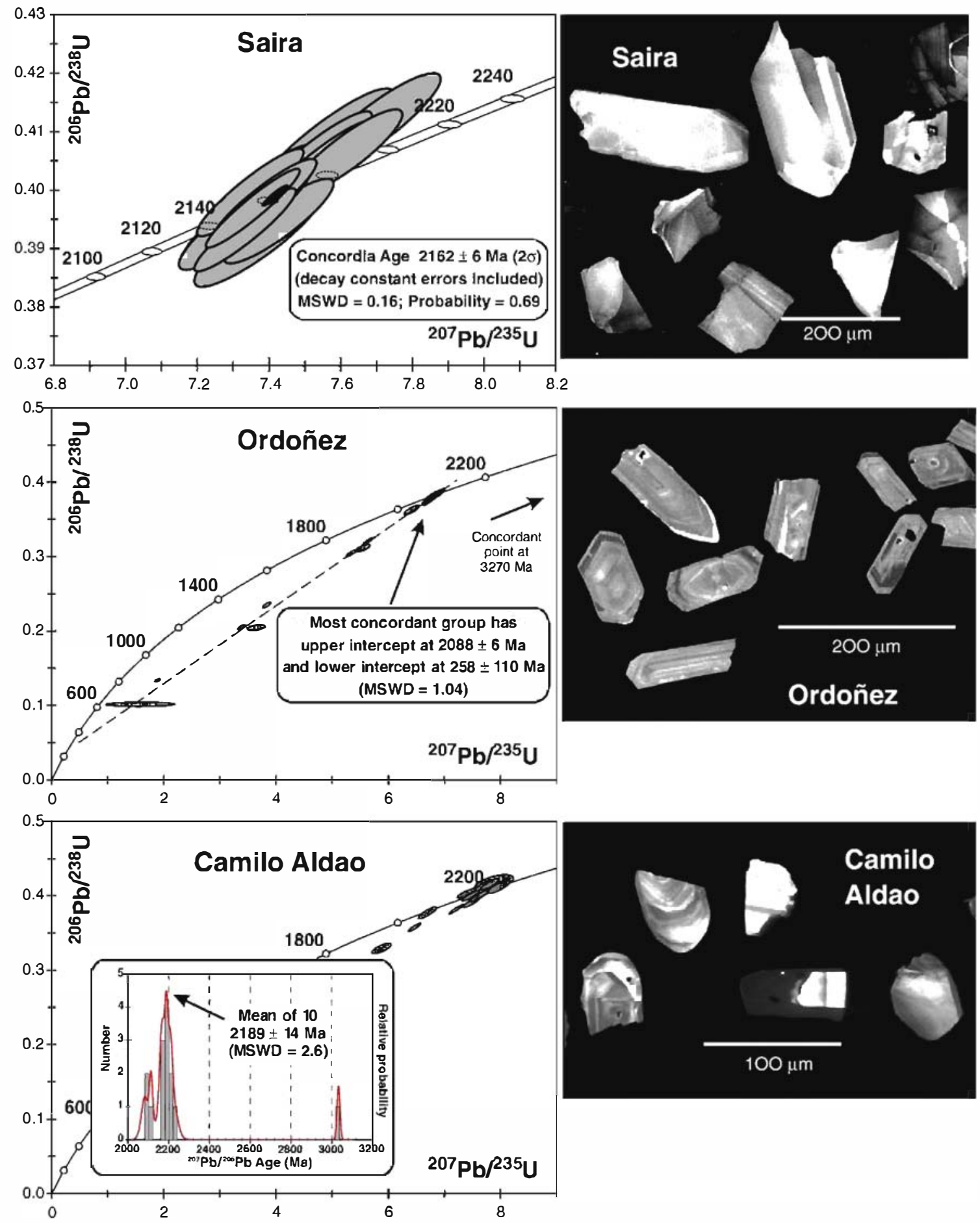

Fig. 8. U-Pb SHRIMP zircon-dating results in borehole samples of the Río de la Plata craton (see Fig. 5). The data are displayed in Wetherill Concordia diagrams with $68.4 \%$ confidence limit error ellipses. The results for Camilo Aldao are also represented in a probability density plot. The right-hand images are cathodoluminescence scans of part of each respective analysed mount (note variable scale). 
microtexture with euhedral and randomly orientated $0.5-1 \mathrm{~mm}$ large porphyroblasts of $\mathrm{Mg}$-homblende $\left(\mathrm{Al}^{\mathrm{iv}}\right.$ $\left.0.7-1.1, \mathrm{Fe}^{*} 0.30-0.37, \mathrm{Na}^{\mathrm{A}} 0.20-0.24\right)$ and $0.5-$ $0.7 \mathrm{~mm}$ of plagioclase (core $\mathrm{An}_{24}$, rim $\mathrm{An}_{30-33}$ ). Both minerals show simple twins, and are surrounded by a grano-lepidoblastic groundmass of Qtz, $\mathrm{Pl}\left(\mathrm{An}_{35}\right)$, Czo $\left(\mathrm{Ps}_{20}\right)$, Ep $\left(\mathrm{Ps}_{30}\right), \mathrm{Bt}\left(\mathrm{Fe}^{*} 0.41\right)$, Fe-Par $\left(\mathrm{Al}^{\mathrm{iv}} 1.56-1.63\right.$, $\left.\mathrm{Fe}^{*} 0.43-0.44, \mathrm{Na}^{\mathrm{A}} 0.38-0.45\right), \operatorname{Tr}\left(\mathrm{Al}^{\mathrm{iv}} 0.38-0.62\right.$, $\left.\mathrm{Fe}^{*} 0.22-0.26, \mathrm{Na}^{\mathrm{A}} 0.06-0.14\right)$, Chl (Fe* 0.41), Ttn, $\mathrm{Ap}$, Ilm, and $\mathrm{Zm}$. The foliation is due to the orientation of groundmass $\mathrm{Fe}$-pargasite and biotite. Increases of $\mathrm{Fe}^{*}, \mathrm{Al}^{\mathrm{iv}}$ and $\mathrm{Na}^{\mathrm{A}}$ in calcic amphibole are strongly temperature dependant (Blundy and Holland, 1990) so that $\mathrm{Fe}$-pargasite is the amphibole that equilibrated at higher temperature. The mineral assemblage $\mathrm{Fe}-\mathrm{Par}+\mathrm{Bt}$ $+\mathrm{Pl}\left(\mathrm{An}_{33-35}\right)+\mathrm{Czo}+\mathrm{Qtz}$ defines the themal peak at $575-595^{\circ} \mathrm{C}(\mathrm{Hbl}-\mathrm{Pl}$ thermometry, H•lland and Blundy, 1994). The assemblage of $\mathrm{Chl}+\mathrm{Tr}+\mathrm{Ep}+\mathrm{Il}+\mathrm{Ttn}$ represents re-equilibration at greenschist-facies conditions during a retrograde metamorphic event. Mg-hornblende and plagioclase porphyroblasts probably preserve compositions previous to the thermal peak.

Ordoñez borehole $\left(32^{\circ} 40^{\prime} S, 62^{\circ} 52^{\prime} \mathrm{W}\right)$. The basement in the Ordoñez borehole is a medium-grained biotite monzogranite that has a primary igneous assemblage composed of plagioclase $\left(\mathrm{An}_{5-10}, 34 \%\right)$, K-feldspar (24\%), quartz (32\%) and accessory minerals (All, Ttn, Zr, Ap, totalling 9\%). Chl, Ms, Ep, Cal, Ilm and Ser are common as low-temperature subsolidus minerals. The granite does not show evidence of metamorphism or deformation, with the exception of microcracks and quartz with undulose extinction formed in a fragile late-stage event.

\subsection{Geochemistry and tectonomagmatic affinities}

Whole-rock chemical analyses and $\mathrm{Nd}$ isotope compositions of the borehole samples are shown in Table 3. Normalized to N-MORB, the Santiago Temple meta-gabbro and the Saira diorite are enriched in large ion lithophile (LIL) elements such as $\mathrm{Cs}, \mathrm{Rb}, \mathrm{Ba}$ and $\mathrm{K}$, and the light rare earth elements (LREE) La and Ce, while they are depleted in high field strength elements such as $\mathrm{Nb}$, Ta, Y and $\mathrm{Zr}$ (Fig. 7a). This pattern is considered typical of subduction zones in which the mantle wedge has been contaminated by fluid release from the subducted slab (e.g. Davidson, 1996). The relative depletion of Ta compared to $\mathrm{Hf}$ and $\mathrm{Th}$ is considered characteristic of basic rocks formed in arc environments; this feature is shown by all four borehole samples, which plot in the arc field of Fig. 7c. Chondrite-normalized REE patterns of the basic rocks
(Santiago Temple and Saira) are flat $\left(\mathrm{La} / \mathrm{Yb}_{\mathrm{cn}}=1.5-1.7\right)$ and sub-parallel, although the Saira diorite shows positive $\mathrm{Sr}$ and $\mathrm{Eu}$ anomalies $\left(\mathrm{Eu} / \mathrm{Eu}^{*}=2.6\right)$ and $\mathrm{Al}_{2} \mathrm{O}_{3}$ enrichment (Fig. 7, Table 3), suggesting plagioclase accumulation. The Camilo Aldao amphibolitic schist $\left(52.9 \% \mathrm{SiO}_{2}\right)$ is a metasedimentary rock derived from an immature siliciclastic rock containing subrounded zircon grains (Fig. 8). The original sediment was probably formed in tum by erosion of basic to intermediate igneous source rocks. It shows a moderately sloping REE pattern $\left(\mathrm{La} / \mathrm{Yb}_{\mathrm{cn}}=6.8\right)$, a small negative Eu anomaly $\left(\mathrm{Eu} / \mathrm{Eu}^{*}=0.9\right)$, and MREE depletion suggesting minor feldspar and amphibole fractionation. The Ordoñez granite $\left(72.5 \% \mathrm{SiO}_{2}\right)$ shows more evolved and distinct patterns (Fig. 7a, b), with an Alumina Saturation Index of 1.03, a steep REE pattern $\left(\mathrm{La} / \mathrm{Yb}_{\mathrm{cn}}=57.6\right)$, a negative Eu anomaly $\left(\mathrm{Eu} / \mathrm{Eu}^{*}=0.6\right)$, MREE depletion and low abundances of high field strength elements such as $\mathrm{Nb}$, Ta and $\mathrm{Y}$.

The $\mathrm{Nd}$ isotope signature of the four samples is primitive, with positive $\varepsilon N d t$ values regardless of the silica content (Table 3). Coupled with the geochemical characteristics, this feature of the analysed basic to intermediate rocks corresponds to that found in intra-oceanic subduction systems (Leat and Larter, 2003) or in primitive continental arcs. Although the Ordoñez granite is also isotopically primitive, its geochemical signature is more evolved than those of felsic igneous rocks usually found in oceanic island arcs (e.g. Smith et al., 2003), suggesting evolution in an arc system emplaced in continental crust. All these juvenile geochemical and isotopic characteristics are otherwise common in 2.0 2.2 Ga rocks in the Brazilian shield corresponding to the Transamazonian orogenic cycle (Cordani et al., 2000).

\section{U-Pb geochronology}

\subsection{Analytical methods}

Zircon grains were separated from total rock samples using standard crushing, washing, heavy liquid (Sp. Gr. 2.96 and 3.3), and paramagnetic separation procedures. For the detrital samples the zircon-rich heavy mineral concentrates were poured onto double-sided tape, mounted in epoxy together with chips of the reference zircons (FC1, and SL13), sectioned approximately in half, and polished. For the geochronology samples, zircon grains were hand-picked and mounted in the same way.

Reflected and transmitted light photomicrographs, and cathodo-luminescence Scanning Electron Microscope (SEM) images were prepared for all zircon grains. 
Table 4

Summary of SHRIMP U-Pb zircon data for crystallization ages

\begin{tabular}{|c|c|c|c|c|c|c|c|c|c|c|c|c|c|c|c|c|c|c|}
\hline \multirow[b]{2}{*}{ Grain. spot } & \multirow[b]{2}{*}{$\begin{array}{l}\mathrm{U} \\
(\mathrm{ppm})\end{array}$} & \multirow[b]{2}{*}{$\begin{array}{l}\text { Th } \\
(\mathrm{ppm})\end{array}$} & \multirow[b]{2}{*}{$\mathrm{Th} / \mathrm{U}$} & \multirow[b]{2}{*}{$\begin{array}{c}{ }^{206} \mathrm{~Pb}^{*} \\
(\mathrm{ppm})\end{array}$} & \multirow[b]{2}{*}{$\begin{array}{l}{ }^{2004} \mathrm{~Pb} / \\
{ }^{206} \mathrm{~Pb}\end{array}$} & \multirow[b]{2}{*}{ f206\% } & \multirow[b]{2}{*}{$\begin{array}{l}{ }^{206} \mathrm{~Pb} / \\
{ }^{238} \mathrm{U}\end{array}$} & \multirow[b]{2}{*}{ \pm} & \multicolumn{5}{|c|}{ Radiogenic ratios } & \multicolumn{5}{|c|}{ Age (Ma) } \\
\hline & & & & & & & & & $\begin{array}{l}{ }^{207} \mathrm{~Pb} / \\
{ }^{235} \mathrm{U}\end{array}$ & \pm & $\begin{array}{l}{ }^{207} \mathrm{~Pb} / \\
{ }^{206} \mathrm{~Pb}\end{array}$ & \pm & $\rho$ & $\begin{array}{l}{ }^{206} \mathrm{~Pb} / \\
{ }^{238} \mathrm{U}\end{array}$ & \pm & $\begin{array}{l}{ }^{207} \mathrm{~Pb} / \\
{ }^{206} \mathrm{~Pb}\end{array}$ & \pm & $\%$ Disc. \\
\hline \multicolumn{19}{|l|}{ Saira } \\
\hline 1.1 & 72.0 & 15.1 & 0.21 & 25.4 & 0.00001 & 0.01 & 0.4113 & 0.0056 & 7.699 & 0.118 & 0.1357 & 0.0010 & 0.89 & 2221.0 & 26.3 & 2173.7 & 12.3 & -2.2 \\
\hline 2.1 & 154.1 & 31.6 & 0.21 & 52.0 & 0.00002 & 0.03 & 0.3935 & 0.0048 & 7.297 & 0.102 & 0.1345 & 0.0009 & 0.87 & 2138.9 & 22.6 & 2157.5 & 12.2 & 0.9 \\
\hline 3.1 & 68.1 & 18.7 & 0.27 & 23.0 & - & $<0.01$ & 0.3919 & 0.0056 & 7.369 & 0.120 & 0.1364 & 0.0010 & 0.88 & 2131.7 & 27.0 & 2181.5 & 13.3 & 2.3 \\
\hline 4.1 & 73.6 & 21.6 & 0.29 & 25.8 & 0.00004 & 0.06 & 0.4078 & 0.0062 & 7.553 & 0.128 & 0.1343 & 0.0010 & 0.90 & 2204.9 & 29.3 & 2155.3 & 13.1 & -2.3 \\
\hline 5.1 & 111.0 & 46.0 & 0.41 & 38.1 & 0.00005 & 0.07 & 0.3997 & 0.0052 & 7.363 & 0.107 & 0.1336 & 0.0009 & 0.89 & 2167.6 & 23.9 & 2145.9 & 11.3 & -1.0 \\
\hline 6.1 & 157.9 & 32.7 & 0.21 & 53.5 & - & $<0.01$ & 0.3946 & 0.0048 & 7.423 & 0.101 & 0.1364 & 0.0009 & 0.88 & 2144.0 & 22.0 & 2182.5 & 11.2 & 1.8 \\
\hline 7.1 & 216.9 & 66.5 & 0.31 & 75.7 & 0.00001 & 0.01 & 0.4063 & 0.0048 & 7.614 & 0.103 & 0.1359 & 0.0009 & 0.88 & 2197.8 & 22.2 & 2175.8 & 11.1 & -1.0 \\
\hline 8.1 & 198.2 & 75.8 & 0.38 & 66.9 & 0.00001 & 0.02 & 0.3931 & 0.0047 & 7.329 & 0.094 & 0.1352 & 0.0007 & 0.93 & 2137.0 & 21.6 & 2167.0 & 8.4 & 1.4 \\
\hline 9.1 & 169.0 & 68.5 & 0.41 & 58.0 & - & $<0.01$ & 0.3996 & 0.0056 & 7.394 & 0.110 & 0.1342 & 0.0007 & 0.94 & 2167.0 & 25.7 & 2153.9 & 8.8 & -0.6 \\
\hline 10.1 & 142.0 & 57.5 & 0.40 & 48.7 & - & $<0.01$ & 0.3994 & 0.0049 & 7.343 & 0.099 & 0.1333 & 0.0007 & 0.92 & 2166.5 & 22.7 & 2142.2 & 9.4 & -1.1 \\
\hline 11.1 & 171.3 & 74.1 & 0.43 & 58.3 & 0.00001 & 0.02 & 0.3962 & 0.0048 & 7.365 & 0.097 & 0.1348 & 0.0007 & 0.92 & 2151.3 & 22.2 & 2161.9 & 9.0 & 0.5 \\
\hline 12.1 & 126.3 & 49.2 & 0.39 & 44.0 & - & $<0.01$ & 0.4055 & 0.0051 & 7.526 & 0.104 & 0.1346 & 0.0008 & 0.91 & 2194.5 & 24.6 & 2158.8 & 10.0 & -1.7 \\
\hline 13.1 & 179.3 & 76.0 & 0.42 & 61.3 & 0.00002 & 0.03 & 0.3980 & 0.0048 & 7.383 & 0.097 & 0.1345 & 0.0007 & 0.91 & 2159.8 & 21.9 & 2158.0 & 9.5 & -0.1 \\
\hline 14.1 & 129.8 & 52.7 & 0.41 & 44.0 & 0.00004 & 0.06 & 0.3945 & 0.0050 & 7.302 & 0.103 & 0.1342 & 0.0008 & 0.89 & 2143.7 & 23.0 & 2154.3 & 11.0 & 0.5 \\
\hline 15.1 & 112.0 & 43.4 & 0.39 & 38.2 & - & $<0.01$ & 0.3974 & 0.0051 & 7.426 & 0.106 & 0.1355 & 0.0008 & 0.91 & 2156.9 & 23.7 & 2170.9 & 10.5 & 0.6 \\
\hline 16.1 & 138.0 & 52.6 & 0.38 & 47.9 & 0.00000 & 0.00 & 0.4043 & 0.0050 & 7.542 & 0.102 & 0.1353 & 0.0007 & 0.91 & 2188.7 & 23.0 & 2167.8 & 9.6 & -1.0 \\
\hline 17.1 & 317.7 & 137.7 & 0.43 & 108.3 & 0.00003 & 0.05 & 0.3967 & 0.0044 & 7.350 & 0.087 & 0.1344 & 0.0005 & 0.95 & 2153.9 & 20.5 & 2155.8 & 6.7 & 0.1 \\
\hline \multicolumn{19}{|c|}{ Camilo Aldao } \\
\hline 1.1 & 47.3 & 33.0 & 0.70 & 15.3 & 0.00000 & 0.01 & 0.3766 & 0.0054 & 6.688 & 0.111 & 0.1288 & 0.0011 & 0.86 & 2060.5 & 25.1 & 2081.7 & 15.0 & 1.0 \\
\hline 2.1 & 207.7 & 201.7 & 0.97 & 68.0 & 0.00001 & 0.01 & 0.3812 & 0.0042 & 7.195 & 0.084 & 0.1369 & 0.0005 & 0.94 & 2081.7 & 19.5 & 2188.5 & 6.8 & 4.9 \\
\hline 3.1 & 259.6 & 79.3 & 0.31 & 79.8 & 0.00010 & 0.15 & 0.3571 & 0.0039 & 6.458 & 0.077 & 0.1312 & 0.0006 & 0.93 & 1968.6 & 18.8 & 2113.5 & 7.9 & 6.9 \\
\hline 4.1 & 27.9 & 36.8 & 1.32 & 10.0 & 0.00007 & 0.10 & 0.4176 & 0.0069 & 7.885 & 0.232 & 0.1369 & 0.0033 & 0.56 & 2249.7 & 31.6 & 2188.9 & 42.3 & -2.8 \\
\hline 5.1 & 95.9 & 69.7 & 0.73 & 32.2 & - & $<0.01$ & 0.3912 & 0.0049 & 7.483 & 0.105 & 0.1387 & 0.0009 & 0.90 & 2128.4 & 22.7 & 2211.5 & 10.8 & 3.8 \\
\hline 6.1 & 342.5 & 197.1 & 0.58 & 158.9 & 0.00004 & 0.05 & 0.5398 & 0.0058 & 16.909 & 0.198 & 0.2272 & 0.0010 & 0.92 & 2782.8 & 24.4 & 3032.3 & 7.4 & 8.2 \\
\hline 7.1 & 49.2 & 55.0 & 1.12 & 13.9 & 0.00015 & 0.23 & 0.3285 & 0.0048 & 5.862 & 0.115 & 0.1294 & 0.0017 & 0.74 & 1831.1 & 23.2 & 2090.1 & 23.2 & 12.4 \\
\hline 8.1 & 83.0 & 111.2 & 1.34 & 29.5 & 0.00000 & 0.01 & 0.4134 & 0.0052 & 7.691 & 0.109 & 0.1349 & 0.0009 & 0.89 & 2230.3 & 23.7 & 2163.2 & 11.5 & -3.1 \\
\hline 9.1 & 120.9 & 52.2 & 0.43 & 43.1 & & $<0.01$ & 0.4151 & 0.0049 & 7.809 & 0.109 & 0.1364 & 0.0010 & 0.85 & 2238.2 & 22.4 & 2182.4 & 12.7 & -2.6 \\
\hline
\end{tabular}




\begin{tabular}{|c|c|c|c|c|c|c|c|c|c|c|c|c|c|c|c|c|c|c|}
\hline 10.1 & 53.4 & 34.9 & 0.65 & 18.6 & 0.00005 & 0.08 & 0.4058 & 0.0061 & 7.540 & 0.207 & 0.1348 & 0.0022 & 0.86 & 2195.7 & 27.8 & 2161.0 & 28.7 & -1.6 \\
\hline 11.1 & 128.0 & 190.8 & 1.49 & 43.9 & - & $<0.01$ & 0.3998 & 0.0049 & 7.457 & 0.100 & 0.1353 & 0.0008 & 0.90 & 2168.2 & 22.3 & 2167.4 & 10.1 & 0.0 \\
\hline 12.1 & 81.8 & 34.9 & 0.43 & 28.3 & 0.00007 & 0.11 & 0.4018 & 0.0051 & 7.590 & 0.122 & 0.1370 & 0.0014 & 0.78 & 2177.5 & 23.3 & 2189.5 & 17.3 & 0.5 \\
\hline 13.1 & 46.0 & 34.1 & 0.74 & 16.3 & - & $<0.01$ & 0.4116 & 0.0059 & 7.959 & 0.138 & 0.1402 & 0.0014 & 0.82 & 2222.3 & 26.8 & 2230.1 & 17.2 & 0.4 \\
\hline 14.1 & 103.8 & 79.5 & 0.77 & 35.6 & 0.00004 & 0.06 & 0.3995 & 0.0048 & 7.615 & 0.104 & 0.1382 & 0.0009 & 0.89 & 2166.9 & 22.3 & 2205.3 & 10.7 & 1.7 \\
\hline \multicolumn{19}{|c|}{ Ordoñez } \\
\hline 1.1 & 597.8 & 157.2 & 0.26 & 107.8 & 0.00147 & 2.45 & 0.2048 & 0.0024 & 3.631 & 0.107 & 0.1286 & 0.0035 & 0.40 & 1200.9 & 12.8 & 2079.1 & 47.5 & 42.2 \\
\hline 2.1 & 426.0 & 273.0 & 0.64 & 111.9 & 0.00016 & 0.24 & 0.3050 & 0.0033 & 5.334 & 0.065 & 0.1268 & 0.0007 & 0.88 & 1716.1 & 16.1 & 2054.4 & 10.1 & 16.5 \\
\hline 3.1 & 398.3 & 229.0 & 0.57 & 129.4 & 0.00011 & 0.17 & 0.3775 & 0.0040 & 6.707 & 0.077 & 0.1289 & 0.0005 & 0.93 & 2064.5 & 18.9 & 2082.6 & 7.3 & 0.9 \\
\hline 4.1 & 389.4 & 241.1 & 0.62 & 127.0 & 0.00002 & 0.03 & 0.3796 & 0.0041 & 6.748 & 0.076 & 0.1289 & 0.0004 & 0.95 & 2074.5 & 19.0 & 2083.3 & 6.1 & 0.4 \\
\hline 5.1 & 562.8 & 243.2 & 0.43 & 181.7 & 0.00009 & 0.14 & 0.3753 & 0.0040 & 6.738 & 0.075 & 0.1302 & 0.0005 & 0.95 & 2054.5 & 18.7 & 2100.6 & 6.2 & 2.2 \\
\hline 6.1 & 389.1 & 250.8 & 0.64 & 129.1 & 0.00005 & 0.07 & 0.3858 & 0.0041 & 6.882 & 0.078 & 0.1294 & 0.0005 & 0.95 & 2103.4 & 19.2 & 2089.5 & 6.3 & -0.7 \\
\hline 7.1 & 365.7 & 265.0 & 0.72 & 120.8 & 0.00034 & 0.51 & 0.3824 & 0.0056 & 6.812 & 0.115 & 0.1292 & 0.0011 & 0.86 & 2087.5 & 26.0 & 2087.1 & 15.2 & 0.0 \\
\hline 8.1 & 421.1 & 311.3 & 0.74 & 132.1 & 0.00031 & 0.48 & 0.3633 & 0.0039 & 6.399 & 0.080 & 0.1277 & 0.0008 & 0.85 & 1997.9 & 18.4 & 2067.1 & 11.5 & 3.3 \\
\hline 9.1 & 390.5 & 306.0 & 0.78 & 129.1 & 0.00001 & 0.02 & 0.3847 & 0.0041 & 6.837 & 0.077 & 0.1289 & 0.0005 & 0.95 & 2098.0 & 19.2 & 2083.2 & 6.2 & -0.7 \\
\hline 10.1 & 2446.4 & 1687.9 & 0.69 & 270.2 & 0.01172 & 20.74 & 0.1019 & 0.0020 & 1.557 & 0.406 & 0.1108 & 0.0288 & 0.07 & 625.6 & 11.5 & 1812.4 & 472.4 & 65.5 \\
\hline 11.1 & 422.2 & 336.5 & 0.80 & 138.8 & 0.00006 & 0.09 & 0.3823 & 0.0041 & 6.812 & 0.078 & 0.1292 & 0.0005 & 0.94 & 2086.8 & 19.2 & 2087.7 & 6.8 & 0.0 \\
\hline 12.1 & 837.6 & 622.1 & 0.74 & 226.6 & 0.00063 & 0.99 & 0.3118 & 0.0034 & 5.537 & 0.085 & 0.1288 & 0.0014 & 0.71 & 1749.5 & 16.8 & 2081.7 & 18.9 & 16.0 \\
\hline 13.1 & 1895.6 & 443.3 & 0.23 & 220.7 & 0.00053 & 0.93 & 0.1343 & 0.0014 & 1.870 & 0.030 & 0.1010 & 0.0012 & 0.65 & 812.1 & 7.8 & 1643.3 & 22.4 & 50.6 \\
\hline 14.1 & 529.0 & 435.6 & 0.82 & 165.6 & 0.00028 & 0.42 & 0.3628 & 0.0042 & 6.418 & 0.090 & 0.1283 & 0.0010 & 0.82 & 1995.6 & 19.8 & 2074.6 & 14.2 & 3.8 \\
\hline 15.1 & 817.6 & 273.7 & 0.33 & 145.2 & 0.00047 & 0.79 & 0.2051 & 0.0021 & 3.372 & 0.047 & 0.1192 & 0.0011 & 0.75 & 1202.7 & 11.5 & 1944.8 & 16.5 & 38.2 \\
\hline 16.1 & 1073.8 & 125.8 & 0.12 & 218.4 & 0.00034 & 0.56 & 0.2354 & 0.0024 & 3.820 & 0.050 & 0.1177 & 0.0009 & 0.80 & 1362.5 & 12.7 & 1921.6 & 14.1 & 29.1 \\
\hline 17.1 & 719.4 & 356.1 & 0.50 & 198.9 & 0.00016 & 0.25 & 0.3210 & 0.0034 & 5.633 & 0.064 & 0.1273 & 0.0005 & 0.93 & 1794.8 & 16.4 & 2060.4 & 7.4 & 12.9 \\
\hline 18.1 & 180.2 & 74.8 & 0.42 & 102.4 & - & $<0.01$ & 0.6616 & 0.0076 & 24.028 & 0.284 & 0.2634 & 0.0008 & 0.97 & 3273.3 & 29.4 & 3267.2 & 4.7 & -0.2 \\
\hline
\end{tabular}

Notes: 1. Uncertainties given at the $1 \sigma$ level.

2. f206\% denotes the percentage of ${ }^{206} \mathrm{~Pb}$ that is common $\mathrm{Pb}$.

3. Correction for common $\mathrm{Pb}$ made using the measured ${ }^{204} \mathrm{~Pb}{ }^{206} \mathrm{~Pb}$ ratio.

4. For $\%$ Disc., $0 \%$ denotes a concordant analysis. 
The cathodo-luminescence images were used to decipher the intemal structures of the sectioned grains and to ensure that the $\sim 20 \mu \mathrm{m}$ SHRIMP spot was wholly within a single age component - usually the youngest for the detrital zircon analyses.

The U-Th-Pb analyses were made using SHRIMPs II, RG and I at the Research School of Earth Sciences, The Australian National University, Canberra, Australia. SHRIMP analytical method follows Williams (1998, and references therein). U/Pb ratios were normalized relative to a value of 0.01859 for the $\mathrm{FC} 1$ reference zircon, equivalent to an age of $1099 \mathrm{Ma}$ (see Paces and Miller, 1993) and data were reduced using the SQUID Excel macro of Ludwig (2001). For the geochronology samples each analysis consisted of 6 scans through the mass range, with the $\mathrm{FC} 1$ reference grains analysed for every three unknown analyses. For the detrital samples, each analysis consisted of 4 scans through the mass range, with a reference zircon analysed for every five unknowns and zircons on the mount were analysed sequentially and randomly up to a total of at least 60 grains for each sample. Data for the geochronology samples are given in Table 4; uncertainties given for individual analyses (ratios and ages) are at the $1 \sigma$ level. Data for the detrital zircon analyses are presented as a Supplementary data to this paper.

Tera-Wasserburg Concordia plots, probability density plots with stacked histograms, and weighted mean ${ }^{206} \mathrm{~Pb} /{ }^{238} \mathrm{U}$ age calculations were carried out using ISOPLOT/Ex (Ludwig, 2003). The "mixture modelling" algorithm of Sambridge and Compston (1994), included in ISOPLOT/Ex, was used to un-mix statistical age populations or groupings; from these groups weighted mean ${ }^{206} \mathrm{~Pb} /{ }^{238} \mathrm{U}$ ages were calculated, with uncertainties reported as $95 \%$ confidence limits.

\subsection{Geochronology of borehole samples}

The zircons from the Saira borehole diorite form a simple population of clear euhedral to subhedral crystals, with pyramidal terminations, or fragments of such grains. Under CL they have broad oscillatory zoning, with relatively large homogeneous areas typical of zircons having crystallized from a mafic magma. The 17 grains analysed yield uniformly concordant data on a Wetherill plot (Fig. 8) with a Concordia age of $2162 \pm$ $6 \mathrm{Ma}$ (MSWD of concordance $=0.16$ ). This is interpreted to be the crystallization age of zircon formed during magmatic emplacement of the diorite.

The Ordoñez granite zircons are elongate crystals, many with bi-pyramidal terminations. The grains are either strongly zoned and cracked, or are simple clear crystals under transmitted light; some have inclusions of apatite. The cathodo-luminescence images show a dominantly simple oscillatory-zoned igneous internal structure. The zircon analysed as grain 18 is anomalous, being a larger, more equant grain with a zoned internal structure. The SHRIMP $\mathrm{U}-\mathrm{Pb}$ analyses range from concordant to significantly discordant, with ${ }^{206} \mathrm{~Pb} /{ }^{238} \mathrm{U}$ ages ranging from $\sim 625$ to $\sim 3275 \mathrm{Ma}$. The analysis of grain 18 is anomalously old and may represent an inherited zircon component or a contaminant from the mineral separation. The other 17 analyses form a linear array on the Wetherill plot (Fig. 8) with an upper Concordia intercept at $\sim 2090 \mathrm{Ma}$ and a poorly defined lower intercept between $\sim 150$ and $370 \mathrm{Ma}$. The discordia line shows that there has been Phanerozoic radiogenic $\mathrm{Pb}$-loss. The upper intercept is well constrained by seven analyses that have a Concordia age of $2086 \pm 4 \mathrm{Ma}$, and this is taken as the crystallization age of the granite.

Scarce zircons obtained from the Camilo Aldao schist are small, up to $100 \mu \mathrm{m}$ in length, subhedral to sub-round grains. Under cathodo-luminescence they show a variety of intemal features from dominantly simple oscillatory zonation to complex structures. Only 14 grains were hand-picked from the heavy mineral concentrate. The SHRIMP U-Pb analyses are also variable, with a single Archaean grain, some discordant areas with an upper Concordia intercept at about $2200 \mathrm{Ma}$ and a subordinate, dispersed series of ${ }^{207} \mathrm{~Pb} /{ }^{206} \mathrm{~Pb}$ ages between $\sim 2200 \mathrm{Ma}$ and $\sim 2100 \mathrm{Ma}$. The analyses do not define a simple discordia trend, but a reasonable interpretation from the relative probability plot of ${ }^{207} \mathrm{~Pb} /{ }^{206} \mathrm{~Pb}$ ages suggests a major zircon crystallization event at $2189 \pm 14 \mathrm{Ma}$, with either subsidiary provenance or radiogenic $\mathrm{Pb}$-loss event at about $2100 \mathrm{Ma}$. There is no evidence for any younger zircon crystallization in this sample.

\subsection{Detrital zircon geochronology}

For the geochronological provenance study, zircon grains were concentrated from two siliciclastic units from the Tandilia belt and four metasedimentary rocks from the Eastern and Western Sierras Pampeanas. The results obtained are presented as both age histograms (Fig. 9) and Tera-Wasserburg Concordia diagrams (Fig. 10).

A basal quartzite of the Sierras Bayas Group (Villa Mónica Formation) was collected from the Barker area of the Tandilia belt, overlying the Palaeoproterozoic basement (sample FSB 260, Fig. 3b, 37 37' 41.05"S, $59^{\circ} 25^{\prime} 05.2^{\prime \prime} \mathrm{W}$ ). It is a highly compacted quartzite with 


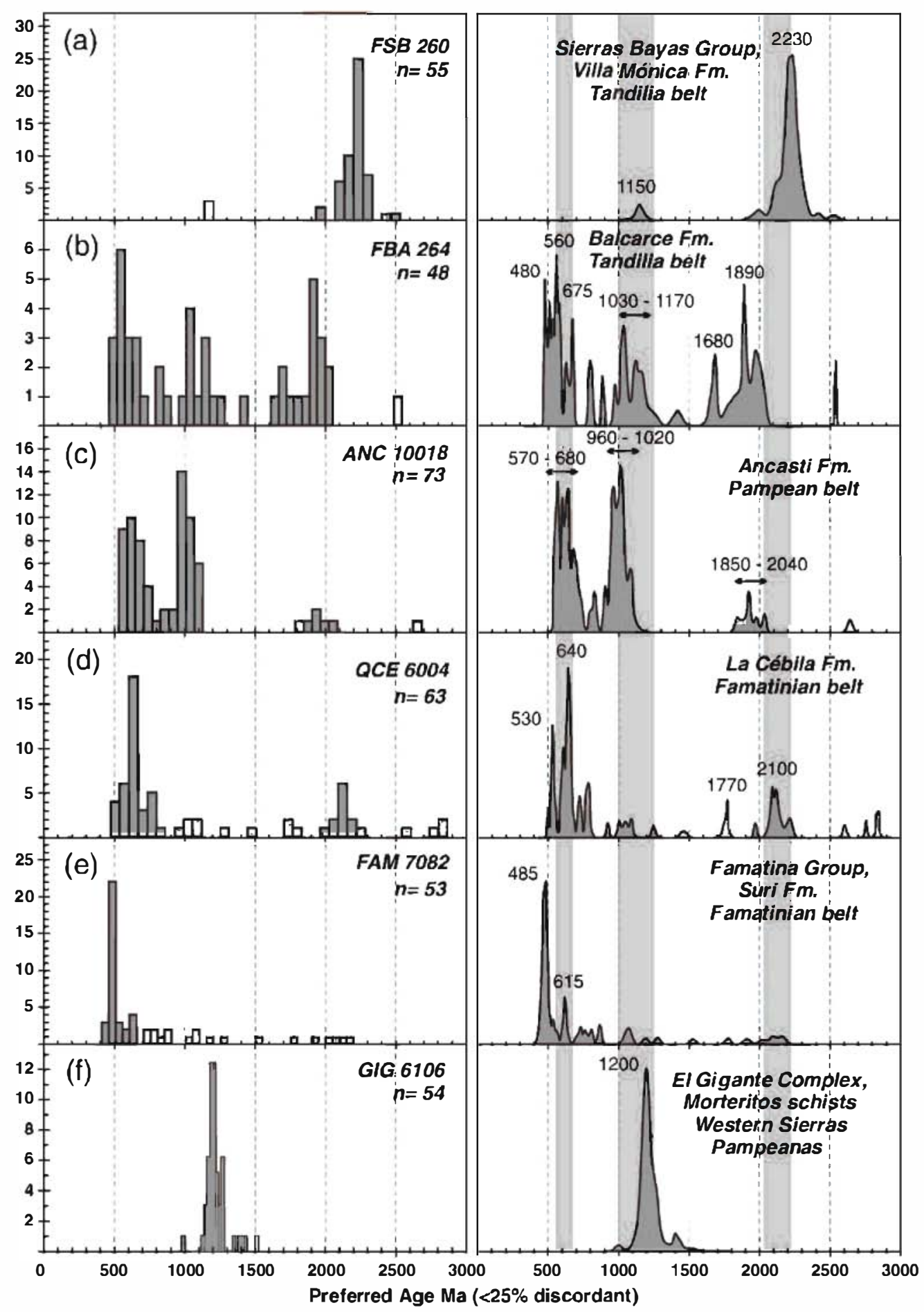

Fig. 9. U-Pb provenance patterns for sedimentary and metasedimentary samples from the Tandilia belt (a, b), the Pampean belt (c), the Famatinian belt (d, e) and the Western Sierras Pampeanas (f). The curves in the right-hand column are relative probability trends (Ludwig, 1999) based on preferred ages derived from individual measurements, which are also shown as histograms in the left-hand column. For ages less than $1000 \mathrm{Ma}$, the ${ }^{238} \mathrm{U}-{ }^{206} \mathrm{~Pb}$ is preferred after correction for initial common $\mathrm{Pb}$ using the ${ }^{207} \mathrm{~Pb}$ measurements; for ages of $1000 \mathrm{Ma}$ and more, the ${ }^{204} \mathrm{~Pb}$-corrected ${ }^{207} \mathrm{~Pb}{ }^{206} \mathrm{~Pb}$ age is preferred. The vertical grey bands represent the nominal age ranges of Brasiliano (540-680 Ma), 'Grenvillian' (1000-1250 Ma) and Transamazonian (2.0-2.2 Ga) orogenic sources. The last only occurs in the Villa Mónica and Famatinian samples, whereas the first two are dominant in the Balcarce and Ancasti (Pampean) samples. 


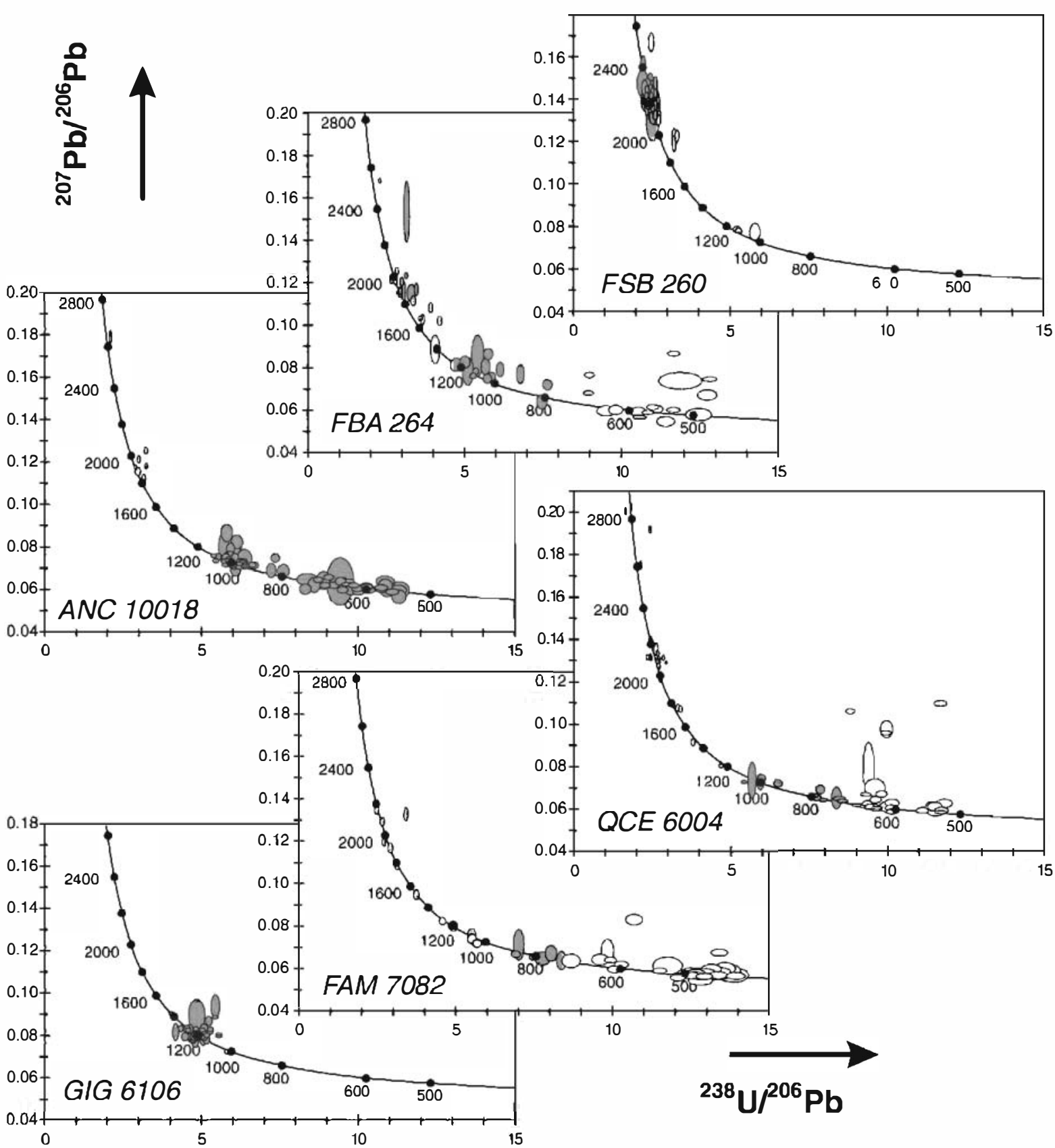

Fig. 10. Tera-Wasserburg Concordia plots for the detrital zircon U-Pb data shown in Fig. 9. To demonstrate concordance, plotted data are corrected for common $\mathrm{Pb}$ as in Table 5, except for the white-filled symbols, where the statistics of the ${ }^{204} \mathrm{~Pb}$ measurement are considered to be too poor for a meaningful correction. A few very discordant points are omitted in some cases.

$>95 \%$ quartz and interstitial smectitic clay. The 55 analysed grains have ages strongly concentrated at $2200 \mathrm{Ma}$ (89\%), with a minor peak at $1150 \mathrm{Ma}$ (Fig. 9a). This indicates that the siliciclastic sequence is mostly derived from the underlying, locally exposed, Palaeoproterozoic basement of the RPC. Analyses of at least three grains are almost concordant at $\sim 1150$ (Fig. 10) which is thus interpreted as approximating their crystallization age; this suggests a distant or restricted Mesoproterozoic source at the time of deposition of the Villa Monica Formation.

The second sample from the Tandilia belt is a quartzite from close to the type area of the Balcarce Formation (sample FBA 264, Fig. 3b, $37^{\circ} 56^{\prime} 59.7^{\prime \prime} \mathrm{S}, 59^{\circ} 19^{\prime}$ 
54.6 "W). It shows grain-to-grain compaction and 3-5\% smectitic clay. Although this sample is located only $80 \mathrm{~km}$ east of the Barker area, the age pattern is remarkably different from that of the Sierras Bayas sample, indicating a completely different source area for the younger siliciclastic platform of the Tandilia belt (Fig. 9b). The zircon population is dominated by Neoproterozoic ("Brasiliano", 675-560 Ma), Mesoproterozoic (1170-1030 Ma) and Late Palaeoproterozoic (1890-1680 Ma) grains (Fig. 9b). A zircon peak as young as $480 \mathrm{Ma}$ gives an estimate for the maximum depositional age of the Balcarce Formation.

Medium to high-grade metasedimentary sequences make up most of the basement of the southern sector of Pampean belt, such as the Sierra de Ancasti and Sierras de Córdoba (Fig. 5). In the Sierra de Ancasti we have sampled the regionally developed banded schists of the Ancasti Formation (Willner et al., 1983). This is characterized by a $\mathrm{N}-\mathrm{S}$ foliation defined by alternation of biotite-rich $0.5 \mathrm{~cm}$ layers and light-coloured 1-2 cm granoblastic layers of Qtz, Pl, Bt and Grt. Sample ANC $10018\left(29^{\circ} 00^{\prime} 30.7^{\prime \prime} \mathrm{S}, 65^{\circ} 27^{\prime} 52.6^{\prime \prime} \mathrm{W}\right)$ has the following mineral assemblage: $\mathrm{Bt}\left(\mathrm{XMg}=0.52, \mathrm{TiO}_{2}\right.$ 1.6\%), Qtz, Pl $\left(\mathrm{An}_{20}\right)$, Ms, Grt (Alm $\left.65, \mathrm{Sp}_{19}\right)$, Ilm/Mag, Tur, Ap, $\mathrm{Zm}$, (Chl). Detrital zircons in the sample have a generally bimodal age distribution, dominated by Mesoproterozoic (1100-960 Ma, 40\%) and Neoproterozoic (680-570 Ma, 40\%) components, with youngest grains indicating a Neoproterozoic depositional age ( $\leq 570 \mathrm{Ma}$ ) (Fig. 9c). A minor component represented by Late Palaeoproterozoic concordant grains is also observed $(\sim 1850 \mathrm{Ma})$, but the absence of concordant zircons in the 2.02-2.26 Ga interval of the RPC is notable (Fig. 10).

In the Quebrada de La Cébila, southwestern Sierra de Ambato (Fig. 5), we sampled quartzo-feldspathic metasedimentary rocks in a medium- to high-grade sequence canying relatively well-preserved Lower Ordovician fossils (Verdecchia et al., 2007). Sample QCE $6004\left(28^{\circ} 43^{\prime} 16.0^{\prime \prime} \mathrm{S}, 66^{\circ} 21^{\prime} 40.0^{\prime \prime} \mathrm{W}\right)$ is a meta quartzarenite with Qtz $\gg \mathrm{Pl}, \mathrm{Kfs}, \mathrm{Bt}, \mathrm{Ms}$, Tr, Cal, Op, Tur, Ap, $\mathrm{Zr}$, with irregular layers richer in biotite and muscovite as well as remnants of cross-bedding structures. The age pattern is dominated by Neoproterozoic zircons with a peak at $640 \mathrm{Ma}(26 \%)$, although the six youngest concordant grains form a discrete subpopulation at $\sim 530 \mathrm{Ma}$ (Fig. 9d), indicating that detrital Cambrian zircons from the nearby Pampean belt were incorporated into the original Ordovician sediment. Less well-defined peaks occur at 790,1770 and $2100 \mathrm{Ma}$, with minor contributions of Mesoproterozoic and Archaean age. The Palaeoproterozoic population from 2200 to
$2000 \mathrm{Ma}$ is defined by 11 grains (17\%), 8 of which are near-concordant; this age interval is coincident with that of the RPC (Fig. 10). Finney et al. (2003, 2004) reported a zircon age distribution pattern from La Cébila determined by ICP-MS (originally mistakenly ascribed to the Lower Cambrian Cerro Totora Formation of the Precordillera). Our results (Figs. 9d and 10) are similar to those labelled "Cerro Totora" (now La Cébila) reported by Finney et al. (2003, their figure 2), but that show an even more pronounced 2.25-2.00 Ga Palaeoproterozoic peak, and thus confirm the age pattern for these Ordovician metasediments.

Farther west, Lower Ordovician Famatinian sedimentary sequences were sampled from Sierra de Famatina (sample FAM 7082, Fig. 5; $29^{\circ} 02^{\prime} 47.8^{\prime \prime} \mathrm{S}$, $\left.67^{\circ} 56^{\prime} 15.9^{\prime \prime} \mathrm{W}\right)$. This sector has been included in the Suri Formation of the Famatina Group (Astini, 2003). This sample is a quartz-feldspar wacke with $>10 \%$ of clay matrix that also contains clastic biotite $(2-3 \%)$ and opaque minerals. The age pattern is dominated by a younger subpopulation with an age peak at $485 \mathrm{Ma}$ (38\%) indicating that this immature volcaniclastic succession was largely derived from coeval Famatinian magmatic rocks (Pankhurst et al., 2000). Minor older peaks appear at $615,900-700,1300-1000$ and four grains between 2200 and $2000 \mathrm{Ma}$, the latter within the typical age range of the RPC (Fig. 9e).

Finally, in Sierra El Gigante (Fig. 5) the most abundant rock type is mica schist, included in Los Morteritos unit by Gardini and Dalla Salda (1997). Our schist sample GIG 6106 (32 51' 26.7"S, 66 54' $05.8^{\prime \prime} \mathrm{W}$ ) is part of a greenschist-facies arenite-to-pelite metasedimentary sequence that alternates with thin layers of marble and amphibolite, all affected by an E-W syn-metamorphic foliation. The mineral association is Qtz, Pl, Kfs, Ms, Bt, Cal, Op, Ap, Zr, (Chl, Ser), and the foliation is defined by lepidoblastic domains of $\mathrm{Ms}+\mathrm{Bt}$ that altemate with granoblastic domains of $\mathrm{Qtz}+\mathrm{Pl}+\mathrm{Kfs}$. The zircon age distribution is unimodal, with a peak at $1200 \mathrm{Ma}$, albeit extending to a minor peak at 1300-1400 Ma (Figs. 9f and 10d). The pattem lacks the ubiquitous Neoproterozoic peak of the Eastem Sierras Pampeanas and the Ordovician sediments (Fig. 9c, d, e), and represents an older Mesoproterozoic component that is usually found in metasedimentary rocks of the Western Sierras Pampeanas (Rapela et al., 2005).

\section{Nd isotope data}

A plot of $\mathrm{Nd}$ model ages $\left(T_{\mathrm{DM}}\right)$ versus stratigraphic ages for the RPC, the Eastern and Western Sierras Pampeanas, the Puncoviscana Formation and the 
Arequipa craton is shown in Fig. 11. Model ages of the borehole samples define a cluster at $\sim 2.3 \mathrm{Ga}$, which is only $140-150 \mathrm{Ma}$ older than the crystallization ages of the basic rocks of Saira and Camilo Aldao, and $\sim 220 \mathrm{Ma}$ older than the Ordoñez granite. This indicates rapid extraction from the mantle for this sector of the RPC. Elsewhere, the Tandilia belt and Piedra Alta terrane show a larger spread in $T_{\mathrm{DM}}$ ages, including many 2.5-2.7 Ga Archaean ages (Fig. 11), indicating a longer period of residence and thus a more mature crustal source. The Nd isotope signature of the Santiago Temple meta-gabbro is similar to that of the other boreholes, while its geochemical trace element pattern is similar and sub-parallel to that of the Saira diorite (Fig. 7), clearly indicating that this gabbro is part of the Palaeoproterozoic complex.

Palaeoproterozoic and (rare) Archaean $T_{\mathrm{DM}}$ ages have been determined in the Northem and Central Domains of the Arequipa massif, as well as in some sectors of the Westem Sierras Pampeanas, but Palaeoproterozoic crystallization ages in the range of the RPC have not been reported from any proto-Pacific terrane (Fig. 11). $T_{\mathrm{DM}}$ model ages in the RPC are older than, and do not overlap with, those in the Pampean belt and the Puncoviscana Formation (Fig. 11). This indicates that the Palaeoproterozoic crust of the RPC was not the source of the igneous rocks of the Pampean belt, nor was it a significant source for the Neoproterozoic to Early Cambrian Puncoviscana and equivalent sedimentary basins.

\section{Discussion}

7.1. Age, metamorphism and isotope signature of the western RPC

A central piece of evidence reported here is that the basement underlying Late Palaeozoic and younger sediments at the western edge of the Chacoparanense basin is Palaeoproterozoic crust. The $2.09-2.19 \mathrm{Ga} \mathrm{U}-\mathrm{Pb}$ SHRIMP crystallization ages obtained from the borehole samples fall within the predominant range of crystallization ages reported for the Tandilia belt, and the Uruguayan and Brazilian terranes of the exposed RPC. All three mafic samples, i.e., the Santiago Temple gabbro, the Saira diorite and the Camilo Aldao amphibolitic schist, underwent at least one metamorphic event that led to partial (or, in the case of Camilo Aldao, complete) transformation of the igneous minerals. Camilo Aldao also developed a synmetamorphic foliation, but in the first two samples deformation is very weak (microfracturing) or absent. The Ordoñez granite does not show evidence of either metamorphism or deformation and is also the youngest of the three dated samples (2088 $\pm 6 \mathrm{Ma}$ ). In consequence, the age of metamorphism and deformation can be well bracketed as Palaeoproterozoic for the entire western sector of the $\mathrm{RPC}$ between $31^{\circ}$ and $33^{\circ} \mathrm{S}$.

Another significant feature of the metamorphism of the mafic rocks is that it was apparently prograde, from

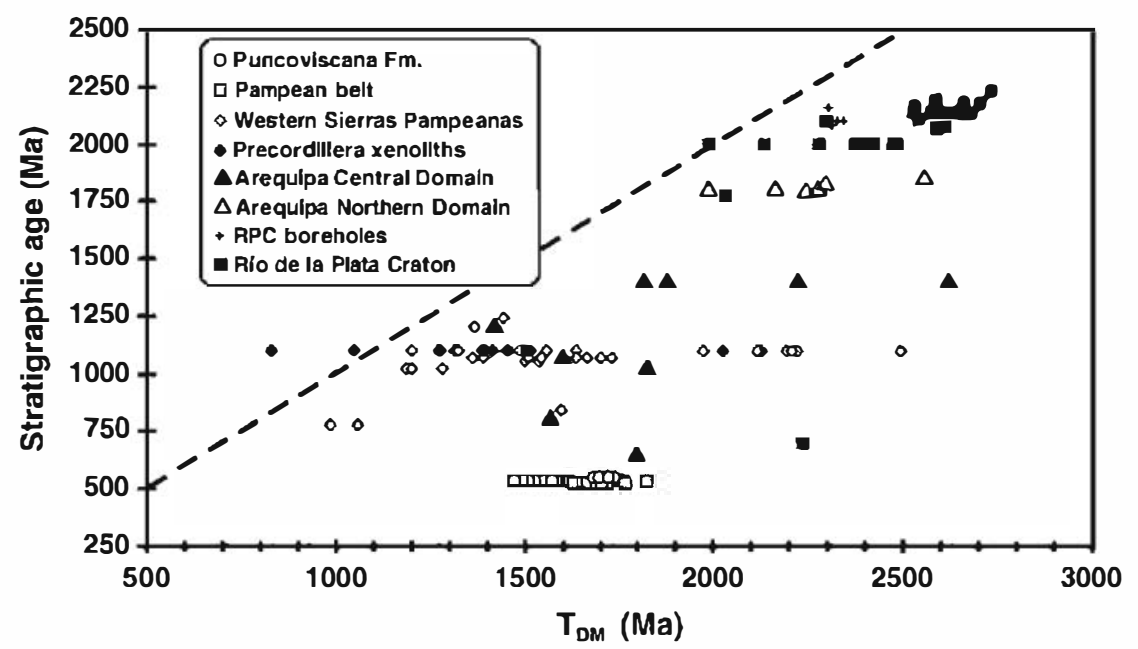

Fig. 11. Stratigraphic age versus $T_{\mathrm{DM}}$ (depleted mantle model ages for crustal sources, DePaolo et al., 1991) for the borehole samples, based on the data in Table 3 for the Río de la Plata craton and significant crustal fragments and units of the southwestern margin of Gondwana. The heavy dashed line is the unique isochron - the closer the samples plot to this line, the more juvenile were their sources. Data sources: Río de la Plata craton (Tandilia belt: Harmann et al., 2002b; Pankhurst et al., 2003; Piedra Alta Terrane: Preciozzi et al., 1999); Arequipa craton (Loewy et al., 2004), Precordillera xenoliths (Kay et al., 1996), Western Sierras Pampeanas (Porcher et al., 2004; Casquet et al., 2005b; Pankhurst, R.J., unpublished data), Pampean belt (Rapela et al., 1998) and the Puncoviscana Formation (Bock et al., 2000). 
low- to medium-grade conditions in the Camilo Aldao and Saira samples, whilst it was apparently retrograde in the Santiago Temple meta-gabbro (amphibolite/granulite to low-grade). Significantly, the Camilo Aldao and Saira samples are relatively close to each other, whereas the Santiago Temple borehole is distant ( ig. 5). We can conclude that the RPC basement under the Chacoparanense sedimentary cover comprises significantly different tectonothermal domains of Palaeoproterozoic age that underwent contrasting evolution during at least one orogenic event.

Three of the borehole samples are basic igneous/ metamorphic rocks with juvenile oceanic island arc signatures ( ig. 7). The Camilo Aldao amphibolitic schist $(2.19 \mathrm{Ga})$ and the Saira diorite $(2.16 \mathrm{Ga})$ are precisely contemporaneous with the dominant rock formation age reported for the Tandilia belt at $\sim 2.15 \mathrm{Ga}$ (total range 2.26-2.07 Ga; Hartmann et al., 2002b; Cingolani et al., 2005). However, the $\mathrm{Nd}$ isotope signatures and model ages of the Tandilia belt $\left(\varepsilon \mathrm{Ndt}=+2.17\right.$ to $-12.2 ; T_{\mathrm{DM}}=$ 2735-2031 Ma; Hartmann et al., 2002b; Pankhurst et al., $203)$ and the Piedra Alta terrane $(\varepsilon N d t=+4.9$ to -1.6 ; $T_{\mathrm{DM}}=2486-1989 \mathrm{Ma}$, recalculated from Preciozzi et al., 1999) extend to much more negative values than those of the borehole samples, which are consistent at +1.5 to +2.6 (Table 3, Fig. 7). This suggests that part of the craton was mature continental crust, dominated in Tandilia and the Piedra Alta terrane by granitic massifs. The rock formation peak at $\sim 2.15 \mathrm{Ga}$ in the Tandilia belt has been ascribed to a major accretionary event, the Encantadas orogeny $(2.25-2.12 \mathrm{Ga})$, recognized in southem Brazil and other Transamazonian terrains (Hartmann et al., 2002a b). In fact, the $2.2-2.0 \mathrm{Ga}$ interval is the main period of continental crust formation in the Brazilian shield (Cordani et al., 2000), and the juvenile basic arc rocks in the western part of the RPC analysed here were clearly part of this extensive event.

The age of the geochemically most evolved borehole sample, the Ordoñez granite (Figs. 7 and 8), is within the error range of the youngest granites in the Tandilia belt (2065 \pm 9 Ma and $2073 \pm 6$ Ma, Hartmann et al., 2002b). At least one $3270 \mathrm{Ma}$ inherited concordant zircon grain suggests contamination from old crust ( ig. 8). In southem Brazil, Uruguay and the Tandilia belt, a second major event was recognized - the collisional Camboriú orogeny $(2.10-2.00 \mathrm{Ga})$, defined by granulite-facies metamorphism and granite formation at shallow crustal levels (Hartmann and Delgado, 2001; Hartmann et al., 2002b). The Ordoñez granite was emplaced during the time interval of the collisional Camboriú orogeny, although its primitive $\mathrm{Nd}$ signature $\left(\varepsilon \mathrm{Ndt}=+1.7 ; T_{\mathrm{DM}}=2312 \mathrm{Ma}\right)$ precludes generation by remelting of Archaean crust. The
REE pattern shows HREE-depletion, suggesting the presence of gamet in the source, while the Eu anomaly indicates moderate feldspar fractionation ( ig. 7). The origin favoured here involves melting of juvenile basic to intermediate island arc source rocks at intermediate pressure during arc accretion to the continent.

\subsection{Boundaries and internal structure of the RPC}

This is the first robust evidence indicating that the main Palaeoproterozoic crustal component of the RPC is also found $500-600 \mathrm{~km}$ to the northwest and west of the typical Atlantic outcrops ( ig. 2). The location of the boreholes, some of them adjacent to the eastern limits of the Sierras Pampeanas, suggests that the Palaeoproterozoic crust extends westwards as far as this Palaeozoic province, leaving no room for any other form of basement province (e.g. the "Chaco terrane" of Keppie and Bahlburg, 1999). In view of the sharp limit between the Sierras Pampeanas and the RPC shown by magnetotelluric studies at $32^{\circ} \mathrm{S}$ (Booker et al., 2004), there is most probably a complex faulted margin between the RPC Palaeoproterozoic crust and the Neoproterozoic to Early Cambrian Pampean belt.

In southern Uruguay, Hartmann et al. (2001) pointed out that the 2.7-3.4 Ga sectors of the Nico Pérez terrane were not affected by the strong $2.07 \mathrm{Ga}$ Palaeoproterozoic event of the nearby Piedra Alta terrane, thus indicating that the two terranes were not formed in the same relative position as today, but that they are an allochthonous collage. On the other hand, Neoarchaean and Palaeoproterozoic crustal blocks in southern Brazil, such as the Tacuarembó block, were affected by the 550-900 Ma tectonothermal events of the Brasiliano cycle (Gastal et al., 2005 and references therein). Taking into account the age, internal characteristics and tectonic boundaries of the terranes and continental blocks that made the RPC, it is useful to make a primary distinction between those composed only of Palaeoproterozoic sequences lacking evidence of Neoproterozoic orogenesis (deformation, metamorphism or granite generation), and those composed of Archaean to Palaeoproterozoic sequences with, in most cases, Neoproterozoic overprints ( ig. 2). Within the first group are the Piedra Alta terrane and the Pando belt in Uruguay, and the Tandilia belt in Argentina. Samples from the western side of the RPC studied in this paper suggest the central western sector of the craton is composed also of Palaeoproterozoic sequences of the first group. In the second group are the Nico Pérez terrane and the Rivera block in Uruguay, the Tacuarembó block in Brazil and the Asunción arch in Paraguay ( ig. 2). Note however that 
similar Neoarchaean and Palaeoproterozoic basement inliers affected by the extensive 660-550 Ma batholiths of the Brasiliano cycle crop out along the coast of southeastern Brazil (Fig. 4), for which reason the northeastern limit of the RPC is somewhat arbitrary.

\subsection{Provenance of the sedimentary basins}

The $\mathrm{U}-\mathrm{Pb}$ crystallization ages reported here for the borehole samples are consistent with $\mathrm{U}-\mathrm{Pb}$ geochronological studies in all exposed sectors of the RPC and other terranes in southern Brazil, which have predominantly yielded crystallization ages in the range 2260 2080 Ma, i.e. Rhyacian, corresponding to the Transamazonian cycle (Hartmann et al., 2002b; Santos et al., 2003 ). This age range, with peaks at $2186 \pm 7 \mathrm{Ma}$ and $2102 \pm 13$ Ma (Hartmann et al., 2002b), is therefore considered the fingerprint age component of the RPC, and is thus key evidence for evaluation of its role as a source during the crustal growth of southern South America. The Neoproterozoic and Lower Palaeozoic siliciclastic units of the Tandilia belt show completely different zircon provenance patterns (Fig. 9a). The $2230 \mathrm{Ma}$ age peak in the Neoproterozoic Sierras Bayas Group (Villa Mónica Fm.) shows provenance dominated by the older Palaeoproterozoic component of the RPC, an age group often found in the TTG island-arc rocks that define the Encantadas orogeny in southern Brazil (Hartmann et al., 2002a). A minor peak at $1150 \mathrm{Ma}$ (Fig. 9a) is the only evidence of a Mesoproterozoic component, and there is no geological evidence to show if these zircons came from a source outside the RPC or whether there are restricted, unexposed Mesoproterozoic sectors within it. The absence of a Neoproterozoic "Brazilian" peak in the Villa Mónica quartzite is significant, suggesting either that the quartz-arenite was deposited before the Neoproterozoic or that the BrazilianPan African arc was located far away from the eastern margin of the RPC. On the other hand, the Palaeozoic Balcarce Fm. does not contain significant detrital zircons in the typical age range of the RPC (Fig. 9b), and the only feasible explanation is provenance from nearby source areas to the east of the RPC, an idea supported by consistently westward palaeocurrents (Fig. 3b). Furthermore, the Neoproterozoic, Mesoproterozoic and Late Palaeoproterozoic detrital age peaks observed in the Balcarce Fm. (Fig. 9b) are characteristics of the Neoproterozoic Rocha Group in the Cuchilla Dionisio terrane (Fig. 3a); they are thus also identical to the patterns shown by the Oranjemund Group of the Gariep belt in Africa (Basei et al., 2005). Such similarity has been taken as conclusive evidence that the Rocha and
Oranjemund groups formed in the same basin, and that their provenance was predominantly from the Kalahari craton, the Namaqua-Natal belt and a 640-590 magmatic arc developed on the African side (Basei et al., 2005). Although it is younger than the Rocha Group, the Balcarce formation has a provenance pattern also suggestive of an African source, located to the east of the Tandilia belt prior to South Atlantic opening.

The bimodal pattem of the Ancasti Formation, with peaks at $1100-960$ and $680-570 \mathrm{Ma}$ (Fig. 9c), is also characteristic of the metasedimentary rocks of the Sierras de Córdoba (Sims et al., 1998; Pankhurst et al., 2000; Schwartz and Gromet 2004; Escayola et al., 2005) and the eastern sector of the Sierra de San Luis (Steenken et al., 2006), indicating that the source area for the whole Pampean belt was dominated by Meso- and Neoproterozoic components. The limited presence of $\sim 1850 \mathrm{Ma}$ Late Palaeoproterozoic zircon in the Ancasti Fm. (Fig. 9c), has been also observed in the Sierras de Córdoba (Schwartz and Gromet, 2004). What is most remarkable in all these patterns is the absence of Palaeoproterozoic peaks in the typical 2.26-2.02 Ga of the RPC. But perhaps the most surprising aspect of the zircon age pattems of the Pampean belt is their equivalence to those in the Oranjemund Group in Africa and the Rocha Group in Uruguay (Basei et al., 2005), indicating an African affinity in the Neoproterozoic basins on both sides of the craton. Furthermore, the zircon patterns of the Cambrian low-grade metasediments that represent the basement of NE Patagonia are also dominated by Neoproterozoic and Mesoproterozoic peaks, with scarce, if any, Palaeoproterozoic zircons in the RPC range of ages (Pankhurst et al., 2006). Consequently, the conclusion concerning relationships between the RPC as a potential source for sediments, and the now adjacent Neoproterozoic to Cambrian basins that surround the craton to the east, south and west, is that there is no relationship. In this sense, it seems the RPC behaved as a "ghost craton", not contributing in any significant amount to these basins (i.e. this differs from previous usage of this terminology, e.g. Leite et al., 2000).

The Ordovician sediments of La Cébila and Famatina, located farther west in the Famatinian belt (Fig. 5), still show a 640-615 Ma Neoproterozoic peak, but a less conspicuous $\sim 1000$ Ma Mesoproterozoic component than in the Pampean belt (Fig. 9d, e). Local provenance indicated by peaks at 530 and $485 \mathrm{Ma}$ is important in both sectors, but what is considered significant are minor groups of 2200-2100 Ma concordant zircons, in the range of the RPC (Figs. 9d, e and 10). These indicate that the RPC was available as a source in Early Ordovician times, marking a very significant contrast with the 
absence of detrital zircon in the Late Neoproterozoic sediments of the Pampean belt. Contributions from an RPC source to the Famatinian belt would be coherent with the present respective terrane locations, showing that the Cambrian was the critical period during which the RPC attained its present position amongst the SW Gondwana fragments.

The unimodal zircon age distribution of the quartz arenite from the Sierra del Gigante, with a peak at $1200 \mathrm{Ma}$ extending to $1300-1400 \mathrm{Ma}$, indicates a dominant source of this age (Figs. 9f and 10d). The most obvious source for these sediments is in the Western Sierras Pampeanas (Fig. 5), where the $1200 \mathrm{Ma}$ age is characteristic of in situ igneous and metamorphic rocks (e.g. Rapela et al., 2005; Casquet et al., 2005b, 2006). Note that detrital zircons with ages in the interval 1400 1200 Ma have not been detected in the Pampean belt, while minor subordinate peaks defined by concordant zircons are observed in the Ordovician sediments of the Famatinian belt (Figs. 9 and 10). The mixed zircon population of the Ordovician sediments shows domination by rapid denudation of local sources, including RPC and Western Sierras Pampeanas components. This suggests that the marine basin of the Famatinian belt received sediments from both eastern and western positive areas, and that the present geographical relationships were established by that time.

\subsection{Palaeomagnetic constraints on Cambrian reconstruction}

A mechanistic explanation for the observed relationships is developed below, but we first present our preferred reconstruction of continental masses at the end of the Early-to-mid Cambrian orogenies (Fig. 12). This is based on the palaeomagnetic model of Trindade et al. (2006), who argued that Amazonia (and the Rio Apa craton) separated from Laurentia but did not join Gondwana until $525 \mathrm{Ma}$ upon closure of the Clymene ocean. Following previous conclusions, we include the Arequipa-Antofalla and, significantly, the Western Sierras Pampeanas basement in this Laurentia-derived assemblage (Casquet et al., 2005b, 2006). The latter area shows evidence for provenance from a $1400 \mathrm{Ma}$ igneous protolith (Fig. 9f; Rapela et al., 2005) not known in other areas of Gondwana. Goodge et al. (2004) ascribed such detritus in the Transantarctic Mountains as having been derived prior to $1000 \mathrm{Ma}$ from the Trans-Laurentian igneous province.

The RPC is joined to the Kalahari craton across the closed Adamastor ocean, as in the model of Basei et al. (2005), as part of the West Gondwana plate assem-

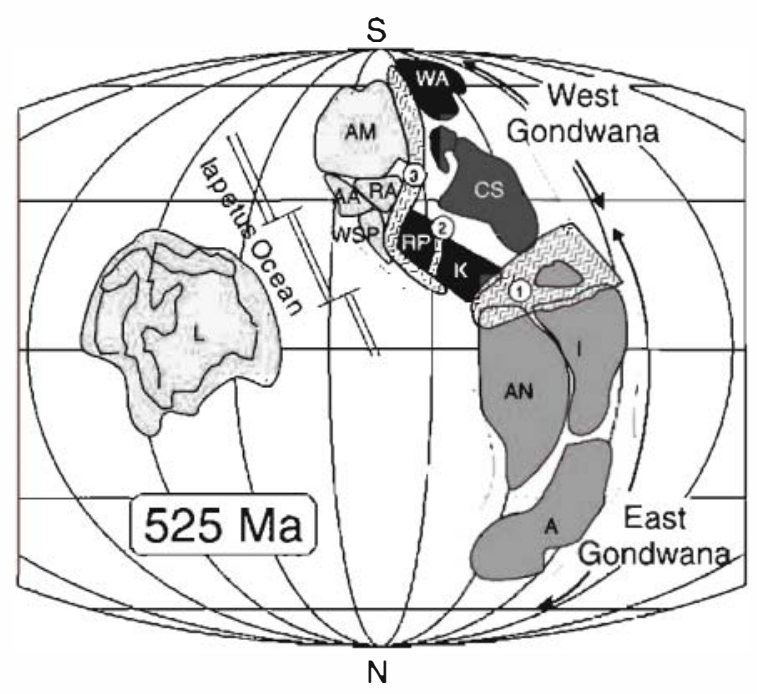

Fig. 12. Palaeogeographical reconstruction for $525 \mathrm{Ma}$ (inverted and modified from Trindade et al., 2006). A: Australia, AN: Antarctica, I: India, CS: Congo-São Francisco, K: Kalahari, WA: West Africa, RP: Río de la Plata, AM: Amazonia, AA: Arequipa-Antofalla, RA: Río Apa, WSP: Western Sierras Pampeanas, L: Laurentia. Light grey shading indicates the Laurentia-Amazonia group of cratons; dark grey, the components of West Gondwana prior to Cambrian collision; mid-grey, those of East Gondwana. Neoproterozoic collisional orogens: (1): East African-Antarctic; (2): Dom Feliciano (3): Pampean-Araguaia. For clarity we have simplified this reconstruction by omitting the ?570-530 Ma Kuunga orogenic belt, which Squire et al. (2006) suggest may be an intra-cratonic belt of relatively little significance, and pre-630 Ma Brasiliano-Pan African belts.

blage. The evolution of East Gondwana is beyond the scope of this paper, apart from its docking with West Gondwana through closure of the Mozambique ocean. The main orogenic belts that formed during the assembly of these fragments are the 650-500 Ma (and older) East African-Antarctic orogen (EAAO) (Jacobs and Thomas, 2004 and references therein) between East and West Gondwana, the joint Gariep and Dom Feliciano belts of Southwest Africa and Brazil-Unuguay, and the Pampean belt of Argentina, together with its northern continuation in the Trans-Brazilian Araguaia belt.

\subsection{Geological constraints on tectonic models}

A tectonic model for the assembly of SW Gondwana involving the Pampean belt, the Famatinian belt and the Western Sierras Pampeanas should take into account the relationships between all these units and the RPC, as well as terranes to the east, an issue that has been so 
far poorly understood. The main constraints discussed above are:

(i) Geophysical evidence shows that the boundary between the RPC and the Pampean mobile belt is a first-order fault; probably active as early as the late Neoproterozoic. The recognition that longitudinal dextral ductile shear zones were associated with contemporaneous magmatism during the
Pampean orogeny (see Section 2.1) suggests that this orogeny was transpressional and right-lateral and not orthogonal as formerly assumed.

(ii) On the eastem margin of the RPC, the Cuchilla Dionisio terrane (part of the Dom FelicianoGariep orogen) was tectonically emplaced against the eastern edge of the Nico Pérez terrane by the sinistral Sierra Ballena Shear Zone (Bossi and Gaucher, 2004). (a) $640-580 \mathrm{Ma}$

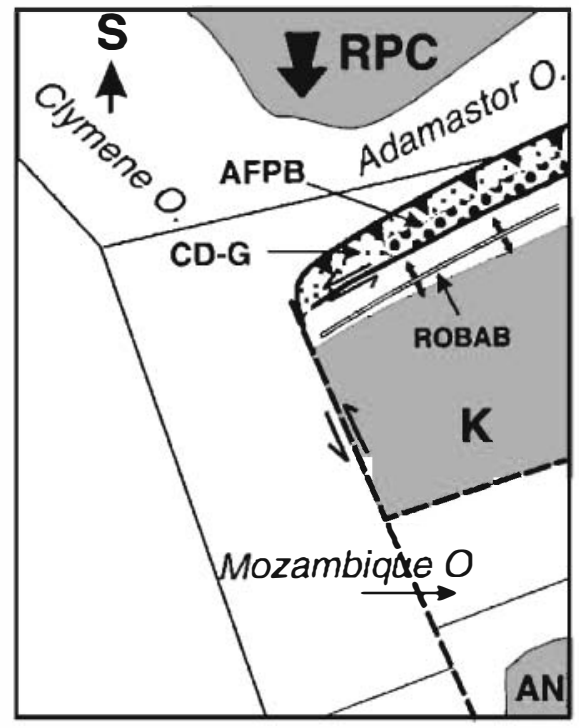

(c) $540-520 \mathrm{Ma}$

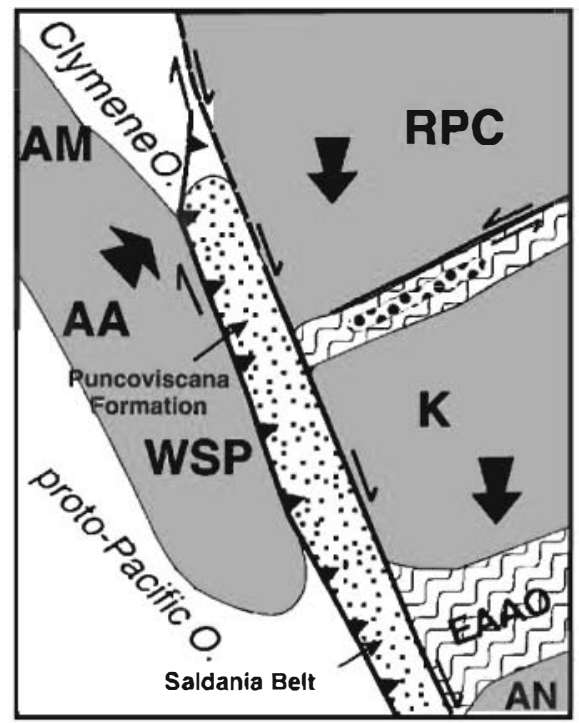
Cratons $\because \because \therefore$ Sedimentary (b) $550-540 \mathrm{Ma}$

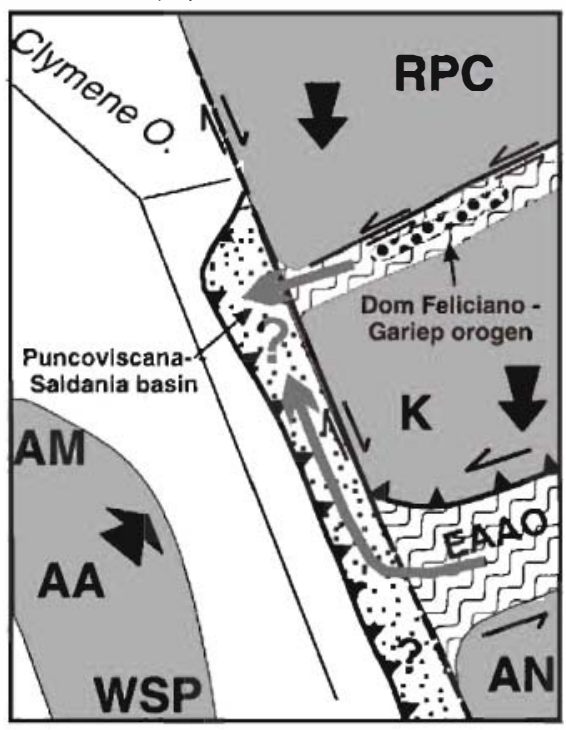

(d) $520-510 \mathrm{Ma}$

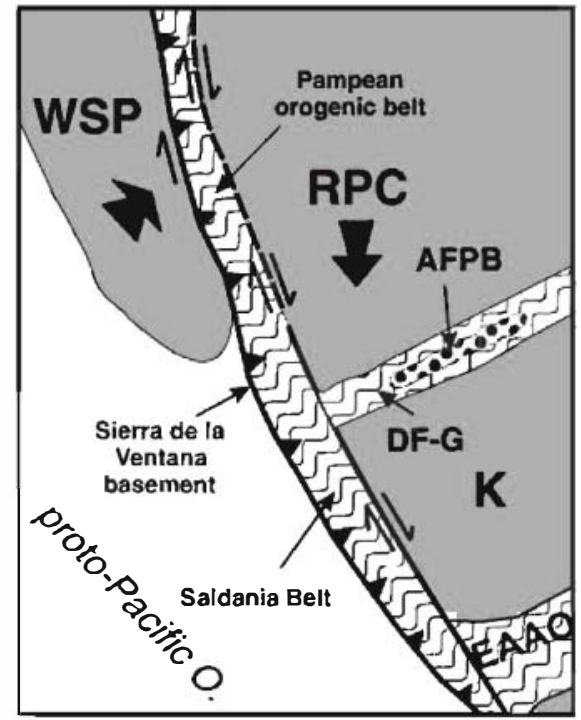

Collisional orogenic belts palaeoflow 
(iii) The sedimentary and metasedimentary rocks of the Pampean belt and the Neoproterozoic basin of the Cuchilla Dionisio terrane do not contain detrital zircon of the typical 2.26-2.02 Ga age range of the RPC, indicating that the RPC is "exotic" to these now neighbouring Neoproterozoic basins. Models depicting the sediments of the Pampean belt as initially formed on a passive margin platform at the western margin of the RPC (e.g. Coira et al., 1982; Ježek et al., 1985; Kraemer et al., 1995; Rapela et al., 1998; Piñán-Llamas and Simpson, 2006) are difficult to reconcile with this absence.

(iv) $T_{\mathrm{DM}}$ model ages of the RPC and the Pampean belt are distinct, also consistent with this conclusion (Fig. 11). Even models that considered the Pampean sediments as formed in a peripheral foreland basin fed mainly from an eastern fold-thrust belt developed on the western edge of the RPC (e.g. Zimmermann, 2005), cannot easily explain the absence of RPC components.

(v) The Pampean model of Escayola et al. (2005) has 700-650 Ma west-dipping subduction with development of a back-arc basin between a Neoproterozoic arc to the east and the foreland of a Grenville-age terrane to the west, culminating in Early Cambrian collision and high-grade metamorphism. However, the postulated Neoproterozoic arc, particularly that corresponding to the dominant $\sim 600 \mathrm{Ma}$ igneous component in the metasedimentary rocks (Fig. 9) and the $\sim 1000 \mathrm{Ma}$ basement accreted against the western edge of the RPC have never been observed in situ, nor can they be inferred in the sub-surface from the evidence presented in this paper.

(vi) The remarkable similarity between the detrital zircon patterns of the Rocha basin and the Oran- jemund group in southern Africa has been explained by a model involving eastward subduction in the proto-Atlantic Adamastor ocean, development of a back-arc basin on the African side (Gariep-Kaoko belts), followed by oblique collision with the schist belt and the Nico Pérez, Rivera and Tacuarembó blocks on the South American side (Basei et al., 2000, 2005). The common detrital pattern is defined by two major peaks at $\sim 600 \mathrm{Ma}$ and $\sim 1000 \mathrm{Ma}$, and a subordinate but well-defined peak at 1700-2000 Ma. The older peaks accord with the pre-Neoproterozoic geology of southwestern Africa (NamaquaNatal belt and Ebumean sectors, respectively; e.g., Eglington, 2006), whereas the $\sim 600$ Ma detrital zircon peak corresponds to the 640-590 Ma age of the Brasiliano batholiths in southwestern Brazil and Uruguay (Fig. 4; Basei et al., 2000). This provenance, with the major peaks at $\sim 600 \mathrm{Ma}$ and $\sim 1000 \mathrm{Ma}$, is also typical of the Neoproterozoic sediments produced by erosion of the EAAO (Squire et al., 2006). This is not surprising, as the southern sector of the Kalahari is dominated by the $\sim 1000$ Ma Natal basement, overprinted by PanAfrican granites of the EAAO (Jacobs and Thomas, 2004).

The compelling conclusion must be that the Neoproterozoic-Early Cambrian sediments of the Pampean belt and the Cuchillo Dionisio Terrane were deposited in an environment with a common provenance that was unrelated to the RPC. Schwartz and Gromet (2004) noted an affinity between the Puncoviscana and Gondwanan sources in South Africa on the basis of ${ }^{207} \mathrm{~Pb} /{ }^{206} \mathrm{~Pb}$ ages for 19 detrital zircon grains and comparison of the ${ }^{207} \mathrm{~Pb} /{ }^{206} \mathrm{~Pb}$ compositions for Pampean igneous rocks, the

\footnotetext{
Fig. 13. Schematic geotectonic model showing the Neoproterozoic to Middle Cambrian assembly of southwestern Gondwana. (a) At 640 Ma the narrow Adamastor ocean that separated the Río de la Plata craton from the western edge of the Kalahari craton started to close, developing a magmatic arc and a wide back-arc basin on the African side (Basei et al., 2005 and references therein). The RPC was separated by the Clymene ocean from the Amazon craton (Trindade et al., 2006). Other associated minor cratons such as Río Apa, Arequipa-Antofalla and the Western Sierras Pampeanas were also attached to the Amazon craton along with Laurentia (Loewy et al., 2004; Casquet et al., 2006). (b) The oblique and left-lateral southward closing of the Adamastor was completed at $545 \mathrm{Ma}$ (Frimmel a d Frank, 1998; Rozendaal et al., 1999), and denudation of this collisional belt developed a large submarine fan of turbidites at the southern tip of the RPC and the Kalahari craton, which may also had been fed by detritus from the East African-Antarctic orogen during closing of the Mozambique ocean (heavy grey arrows show probable transport directions) and from the Grenville-age Namaqua-Natal belt. Dextral displacement of the fore-arc turbidite deposits of the Puncoviscana Formation and the Saldanian Belt started along the western margin of the newly assembled RPC-Kalahari continental block. Closure of the Clymene ocean was taking place at this time. (c) The last major episode of accretion in southwestern Gondwana developed at 540-520 Ma with the right-lateral collision (the Pampean orogeny) between Arequipa-Antofalla and the Western Sierras Pampeanas cratons and the Puncoviscana Formation foreland. Widespread anatexis and peraluminous magmatism (525-520 Ma) represent the culmination of the Pampean orogeny, which was preceded by emplacement of metaluminous calc-alkaline plutons (540-530 Ma) (Rapela et al., 1998). (d) Continued right-lateral movement displaced the Pampean mobile belt to its present position alongside the Río de la Plata craton. Abbreviations: RPC, Río de la Plata craton; K, Kalahari craton; AM, Amazonia; AA, Arequipa-Antofalla terrane; WSP, Western Sierras Pampeanas; ROBAB, Rocha/Oranjemund back-arc basin; AFPB, Aiguá-Florianópolis-Pelotas batholith; EAAO, East African-Antarctic orogen; DF-G, Dom Feliciano-Gariep orogen; AN, Antarctica.
} 
former now fully justified by the data presented here. They proposed that the Puncoviscana Formation was deposited in a trough marginal to the Kalahari craton, and was later emplaced against the westem margin of the RPC by lateral strike-slip displacement.

\subsection{Tectonic model}

The model begins at 780 to $750 \mathrm{Ma}$ with the progressive opening of the proto-Atlantic Adamastor ocean as part of the break-up of Rodinia (Rozendaal et al., 1999). Also at this time, the Clymene ocean separated what subsequently became West Gondwana from the Amazonia craton group (Trindade et al., 2006); A-type magmatism in the Western Sierras Pampeanas dated at $774 \pm 6 \mathrm{Ma}$ (Baldo et al., 2006) is consistent with early rifting heralding separation of the latter from Laurentia (Tollo et al., 2004).

Inversion of the Adamastor ocean began as early as $640 \mathrm{Ma}$ (Fig. 13a) by southward subduction and development of a large back-arc basin along the westem margin of the Kalahari craton (Basei et al., 2005), although a northward subduction vector has been inferred by others (Frimmel et al., 1996; Saalman et al., 2006). A magmatic arc represented by the large Aiguá-Florianopolis-Pelotas batholiths of southern Brazil and Uruguay developed between 640 and $590 \mathrm{Ma}$. The age of equivalent calcalkaline granites decreases from north to south (Basei et al., 2000), suggesting that opening of the back-arc basin started in the north. Ar-Ar ages of $600 \pm 7 \mathrm{Ma}$ and $610 \pm 16 \mathrm{Ma}$ obtained from amphibole in mafic rocks of the Marmora terrane (Gariep belt), are minima for the timing of oceanic crust formation in the back-arc basin (Frimmel and Fölling, 2004). The siliciclastic rocks of the Rocha Group of the Punta del Este terrane (Dom Feliciano belt, Uruguay) and those of the Oranjemund Group of the Pan-African Gariep Belt of SW Africa, were deposited in this common back-arc basin between at least $600 \mathrm{Ma}$ and $500 \mathrm{Ma}$ (Basei et al., 2005).

Closing of the Adamastor ocean along the western margin of the Kalahari occurred simultaneously with sinistral closure of the Mozambique ocean than led to the collisional EAAO (Jacobs and Thomas, 2004). The terminal areas of both the Dom Feliciano-Gariep orogen and the EAAO are the proposed sources of the sediments of the Puncoviscana Formation (Pampean belt), and the probably correlative sedimentary successions of the Saldania belt deposited along the southern margin of the Kalahari craton (Fig. 13b). Detrital zircon age pattems in the Pampean belt are compatible with provenance from a Grenville-age source (such as the Namaqua-Natal belt) and Brasiliano-Pan-African source (such as the Dom Feliciano and EAAO orogenic belts). The Saldania belt is largely composed of Neoproterozoic siliciclastic sedimentary sequences that were intruded by granitoids of the Cape granite suite with ages (S- and I-type only) between ca. 550 and $520 \mathrm{Ma}$ (Da Silva et al., 2000; Scheepers and Armstrong, 2002). This age interval embraces that of the recorded I- and S-type plutonism in the Pampean belt and the I- and A-type plutonism in the basement of the Sierra de la Ventana (538-520 Ma). The Saldania belt is unconformably overlain by the post-orogenic Kansa Subgroup molasse with a maximum sedimentation age of ca. 520 Ma (Barnett et al., 1997). The Saldanian orogeny in South Africa thus took place in the Late Neoproterozoic and the Early Cambrian and is here correlated with the Pampean orogeny.

Final collision of the RPC with the Kalahari craton (Fig. 13c) took place at ca. $545 \mathrm{Ma}$ (Frimmel and Frank, 1998). Subduction and collision during this orogenic cycle (Brasiliano-Pan-African orogeny) were oblique and left-lateral (Rozendaal et al., 1999; and references therein). The sinistral Sierra Ballena Shear Zone referred to above, which separates the RPC from the Cuchilla Dionisio terrane in Uruguay, probably represents one of the shear zones along which lateral accretion of terranes took place during this orogeny (e.g., the Dom Feliciano belt; Bossi and Gaucher, 2004).

Following collision of the RPC with the Kalahari craton, continued southward (relative) movement of the new combined Río de la Plata and Kalahari continent, along with a correlative oblique approach of the Amazonia craton group from the southwest, led to the progressive closure of part of the Clymene ocean, triggering the Pampean-Saldanian orogenies along the southern and westem active margins of Kalahari and Río de la Plata cratons respectively (Fig. 13b, c). Collision may have been complete in the case of the Pampean mobile belt, but incomplete in the case of the low-grade Saldanian belt. Northward continuation of the Pampean into the Araguaia orogen of Brazil (Trindade et al., 2006) suggests that collision involved a very long section of both the Clymene margin and the proto-Pacific margin of Gondwana.

Protracted late- and post-orogenic right-lateral movement of the Araguaia-Pampean-Saldanian belts along the southem margin of the Río de la Plata and Kalahari cratons led to their final position (Figs. 12, 13d).

\section{Conclusions}

The new geochronological results presented here for drill-core material in western Argentina show that early Palaeoproterozoic $(2.3-2.0 \mathrm{Ga})$ igneous rocks 
of the Río de la Plata craton extend over approximately $1000 \mathrm{~km} \mathrm{E-W}$, from the Tandilia outcrops on the Atlantic coast to within about $\sim 20 \mathrm{~km}$ of outcrops of the Pampean belt around Córdoba. This, together with the positive $\varepsilon \mathrm{Ndt}$ values of the borehole material, reinforces the idea that the craton is dominated by juvenile rocks of that age that have suffered very little subsequently tectonothermal history, except for Neoproterozoic and Palaeozoic rejuvenation noted in the northeastern outcrops of the craton (Fig. 2).

However, sedimentary rocks deposited both on the RPC and in the orogenic belts on its western flank rarely show input of detrital zircons derived from 2.3 to $2.0 \mathrm{Ga}$ sources, essentially eliminating the possibility of significant provenance from the craton. The absence of such detritus is particularly striking in the metasedimentary sample of the Pampean orogenic cycle immediately adjacent to the western margin, and it only reappears in the Early Ordovician rocks of the Famatinian belt. This absence, and the presence instead of $\sim 600 \mathrm{Ma}$ and $\sim 1000 \mathrm{Ma}$ detritus is notable in data published by other authors (see Section 7.3). This is explained in our model by deposition of the Neoproterozoic Pampean sediments as a voluminous fore-arc sequence along the proto-Pacific margin, derived from erosion of the 680-540 Ma (Dom Feliciano-Gariep) and East African-Antarctic (EAAO) collisional belts located at either side of the southern Kalahari (Fig. 13). These orogens are superimposed on the 1000 Ma Namaqua-Natal belt, which is a potential source for the $\sim 1000 \mathrm{Ma}$ detrital zircons in the Pampean and Famatinian belts and an alternative to the 'Grenville-age' basement of the Western Sierras Pampeanas.

The key feature of this model is the Early Cambrian oblique dextral collision of a large Laurentia-derived block (Amazonia, Arequipa and the Western Sierras Pampeanas) with the Pampean belt (Fig. 13c). A dextral shear zone occurred at the contact between the RPC and the Pampean belt, now hidden beneath the Chacoparanense basin, and is inferred here to be the southern extension of the Transbrasiliano lineament (Cordani et al., 2003), which has been previously placed farther east (Leal et al., 2003) (Fig. 5). This involved also protracted relative displacement of the RPC after the Pampean Orogeny, dextral on the proto-Pacific flank and sinistral on the proto-Atlantic one.

The rather short-lived Pampean orogeny is thus dominated by transpressional structures and dextral mylonitic belts (Martino, 2003; von Gosen and Prozzi, 2005), along with high $T-P$ metamorphism and lateorogenic anatexis that generated peraluminous magma- tism farther south in the Pampean belt (Rapela et al., 1998). Large volumes of late-tectonic A2-type granites intruded ca. 530-490 Ma are characteristic of this stage in the southem part of the East African-Antarctic orogen (Jacobs and Thomas, 2004), as well as in the Sierra de la Ventana (Rapela et al., 2003).

Although this represents a significant and radical revision of Gondwana assembly models, many details remain elusive. Variants of the collisional back-arc and transcurrent models, such as those described above, are still possible alternatives, and the presence of possible $\sim 1000 \mathrm{Ma}$ belts in the zone between the Río de la Plata craton and Patagonia remains a possibility. Future precise palaeomagnetic studies in the Neoproterozoic basins and Hf determinations in the detrital zircon populations may be able to provide additional constraints.

\section{Acknowledgements}

Financial support for this paper was provided by Argentine public grants FONCYT PICT 07-10735 and CONICET PIP 5719 as well as the Spanish MEC grants BTE2001-1486 and CGL2005-02065/BTE, Universidad Complutense grant PR1/05-13291. R.J.P. acknowledges a NERC Small Research Grant. REPSOL-YPF allowed the study of the drill core samples from the Chacoparanense basin. L. Spalletti helped with the sampling of the Río de la Plata platform and, together with C. Gaucher and R. Trindade, is especially thanked for comments on several aspects of the manuscript. A. Benialgo helped with the digital images while S. Matheos advised on the fabric and mineralogy of the sedimentary rocks. J. Otamendi and one anonymous reviewer are thanked for their constructive comments.

\section{References}

Aceñolaza, F., Aceñolaza, G., 2005. La Formación Puncoviscana y unidades estratigráficas vinculadas en el Neoproterozoico-Cámbrico temprano del noroeste argentino. Latin American Journal of Sedimentology and Basin Analysis 12, 65-87.

Astini, R.A., 2003. The Ordovician proto-Andean basins. In: Benedetto, J.L. (Ed.), Ordovician fossils of Argentina. Secretańa de Ciencia y Tecnología, Universidad Nacional de Córdoba, pp. 1-74.

Astini, R.A., Benedetto, J.L., Vaccari, N.E., 1995. The Early Paleozoic evolution of the Argentine Precordillera as a Laurentian rifted, 
drifted and collided terrane: a geodynamic model. Geological Society of America Bulletin 107, 253-273.

Baldo, E., Dahlquist, J., Rapela, C.W., Casquet, C., Pankhurst, R.J., Galindo, C., Fanning, C.M., 2005. Early Ordovician peraluminous magmatism in the Sierra de Pie de Palo (Western Sierras Pampeanas): geotectonic implications. In: Pankhurst, R.J., Veiga, G.D. (Eds.), Gondwana 12: Geological and Biological Heritage of Gondwana, Abstracts. Academia Nacional de Ciencias, Córdoba, Argentina, p. 57.

Baldo, E., Casquet, C., Pankhurst, R.J., Galindo, C., Rapela, C.W., Fanning, C.M., Dahlquist, J., Murra, J., 2006. Neoproterozoic Atype magmatism in the Western Sierras Pampeanas (Argentina): evidence for Rodinia break-up along a proto-Iapetus rift? Terra Nova 18, 388-394.

Barnett, W., Armstrong, R.A., de Wit, M.J., 1997. Stratigraphy of the upper Neoproterozoic Kango and lower Palaeozoic Table Mountain Groups of the Cape Fold Belt revisited. South African Journal of Geology 100, 237-250.

Basei, M.A.S., Siga Jr., O., Masquelin, H., Harara, O.M., Reis Neto, J.M., Preciozzi, F., 2000. The Dom Feliciano belt of Brazil and Uruguay and its foreland domain, the Río de la Plata craton: framework, tectonic evolution and correlation with similar provinces of southwestern Africa. In: Cordani, U.G., Milani, E.J., Thomaz Filho, A., Campos, D.A. (Eds.), Tectonic Evolution of South America. 31st Intemational Geological Congress, Rio de Janeiro, pp. 311-334.

Basei, M.A.S., Frimmel, H.E., Nutman, A.P., Preciozzi, F., Jacob, J., 2005. A connection between the Neoproterozoic Dom Feliciano (Brazil/Uruguay) and Gariep (Namibia/South Africa) orogenic belts - evidence from a reconnaissance provenance study. Precambrian Research 139, 195-221.

Berman, R.G., 1991. Thermobarometry using multi-equilibrium calculations: a new technique, with petrological applications. Canadian Mineralogist 29, 833-855.

Blundy, J., Holland, T.J.B., 1990. Calcic amphibole equilibria: a new amphibole-plagioclase geothermometer. Contributions to Mineralogy and Petrology 104, 208-224.

Bock, B., Bahlburg, H., Wörner, G., Zimmermann, U., 2000. Tracing crustal evolution in the Southern Central Andes from Late Precambrian to Permian with geochemical and $\mathrm{Nd}$ and $\mathrm{Pb}$ isotope data. Journal of Geology 108, 513-535.

Booker, J.R., Favetto, A., Pomposiello, M.C., 2004. Low electrical resistivity associated with plunging of the Nazca flat slab beneath Argentina. Nature 429, 399-403.

Bossi, J., Campal, N., 1992. Magmatismo y tectónica transcurrente durante el Paleozoico Inferior en Uruguay. In: Gutierrez Marco, J.C., Saavedra, J., Rábano, I. (Eds.), Paleozoico Inferior de Iberoamérica. Universidad de Extremadura, pp. 343-356.

Bossi, J., Gaucher, C., 2004. The Cuchilla Dionisio Terrane, Uruguay: an allochthonous block accreted in the Cambrian to SWGondwana. Gondwana Research 7, 661-674.

Bossi, J., Piñeiro, D., Cingolani, C.A., 2005. El límite sur del Terreno Piedra Alta (Uruguay). Importancia de la faja milonítica sinistral de Colonia. $16^{\circ}$ Congreso Geológico Argentino, Actas I, pp. 173-180.

Caminos, R., 1979. Sierras Pampeanas Noroccidentales. Salta, Tucumán, Catamarca, La Rioja y San Juan. Segundo Simposio de Geología Regional Argentina I, pp. 226-291.

Casquet, C., Baldo, E., Pankhurst, R.J., Rapela, C.W., Galindo, C., Fanning, M., Saavedra, J., 2001. Involvement of the Argentine Precordillera Terrane in the Famatinian mobile belt: geochronological (U-Pb SHRIMP) and metamorphic evidence from the Sierra de Pie de Palo. Geology 29, 703-706.
Casquet, C., Rapela, C.W., Pankhurst, R.J., Galindo, C., Dahlquist, J., Baldo, E.G., Saavedra, J., González-Casado, J.M., Fanning, C.M., 2005a. Grenvillian massif-type anorthosites in the Sierras Pampeanas. Journal of the Geological Society, London 162, 9-12.

Casquet, C., Pankhurst, R.J., Rapela, C.W., Fannning, C.M., Galindo, C., Baldo, E., González-Casado, J.M., Dahlquist, J., Saavedra, J., 2005b. The Maz suspect terrane: a new Proterozoic domain in the Western Sierras Pampeanas. In: Pankhurst, R.J., Veiga, G.D. (Eds.), Gondwana 12: Geological and Biological heritage of Gondwana, Abstracts, p. 92.

Casquet, C., Pankhurst, R.J., Fanning, C.M., Baldo, E., Galindo, C., Rapela, C.W'., González-Casado, J.M., Dahlquist, J.A., 2006. U-Pb SHRIMP zircon dating of Grenvillian metamorphism in Western Sierras Pampeanas (Argentina): correlation with the Arequipa Antofalla craton and constraints on the extent of the Precordillera Temane. Gondwana Research 9, 524-529.

Cingolani, C.A., Bonhomme, M.G., 1982. Geochronology of La Tinta Upper Proterozoic sedimentary rocks, Argentina. Precambrian Research 18, 119-132.

Cingolani, C.A., Varela, R., 1999. The San Rafael block, Mendoza (Argentina): $\mathrm{Rb}$-Sr isotopic age of basement rocks. II South American Symposium on Isotope Geology, Villa Carlos Paz, Argentina. Servicio Geológico Minero Argentino, Anales, vol. XXXIV, pp. 23-26.

Cingolani, C.A., Santos, J.O.S., MeNaughton, N.J., Hartmann, L.A., 2005. Geocronología U-Pb SHRIMP sobre circones del granitoide Montecristo, Tandil, provincial de Buenos Aires, Argentina. $16^{\circ}$ Congreso Geológico Argentino, Actas I, pp. 299-302.

Coira, B.L., Davidson, J., Mpodozis, C., Ramos, V., 1982. Tectonic and magmatic evolution of the Andes of northern Argentina and Chile. Earth-Science Reviews 18, 303-332.

Coira, B.L., Manca, N., Chayle, W.E., 1990. Registros volcánicos en la Formación Puncoviscana. In: Aceñolaza, F.G., Millar, H., Toselli, A.J. (Eds.), El Ciclo Pampeano en el noroeste argentino. Serie Correlación Geológica, vol. 4. Universidad Nacional de Tucumán, pp. 53-60.

Cordani, U.G., Sato, K., Teixeira, W., Tassinari, C.C.G., Basei, M.A. S., 2000. Crustal evolution of the South American platform. In: Cordani, U.G., Milani, E.J., Thomaz-Filho, A., y Campos, D.A. (Eds.), Tectonic Evolution of South America, 31st International Geological Congress, Río de Janeiro, pp. 19-40.

Cordani, U.G., Cubas, N., Nutman, A.P., Sato, K., Gonzalez, M.E., Presser, J.L.B., 2001. Geochronological constraints for the evolution of the metamorphic complexes near the Tebicuary river, southern Precambrian region of Paraguay. III South American Symposium on Isotope Geology, Pucon, Chile, pp. 113-116. CD-ROM.

Cordani, U.G., D'Agrella-Filho, M.S., Brito-Neves, B.B., Trindade, R.I.F., 2003. Tearing up Rodinia: the Neoproterozoic palaeogeography of South American cratonic fragments. Terra Nova 15, 350-359.

Dahlquist, J.A., Pankhurst, R.J., Rapela, C.W., Galindo, C., Alasino, P., Casquet, C., Fanning, C.M., Saavedra, J., Baldo, E., GonzálezCasado, J., 2005. New SHRIMP ages in the Sierra de Famatina, NW Argentina: implications for the Famatinian Orogen. In: Pankhurst, R.J., Veiga, G.D. (Eds.), Gondwana 12: Geological and Biological Heritage of Gondwana. Academia Nacional de Ciencias, Córdoba, Argentina, p. 123. Abstracts.

Dalla Salda, L., Iñiguez, A.M., 1979. La Tinta, Precámbrico y Paleozoico de Buenos Aires. $7^{\circ}$ Congreso Geológico Argentino, Actas 1, pp. 539-550.

Dalla Salda, L., Bossi, J., Cingolani, C., 1988. The Río de la Plata cratonic region of southwestern Gondwana. Episodes 11, 263-269.

Dalla Salda, L., de Barrio, R.E., Etcheveste, H.J., Fernández, R.R., 2005. El basamento de las Sierras de Tandilia. In: de Barrio, R.E., 
Etcheverry, R.O., Caballé, M.F., Llambías, E. (Eds.), Geología y Recursos Minerales de la Provincia de Buenos Aires. Relatorio del $16^{\circ}$ Congreso Geológico Argentino IV, pp. 31-50.

Da Silva, L.C., Gresse, P.G., Scheepers, R., McNaughton, N.J., Hartmann, L.A., Fletcher, I., 2000. U-Pb SHRIMP and Sm-Nd age constraints on the timing and sources of the Pan-African Cape Granite Suite, South Africa. Journal of African Earth Sciences 30, 795-815.

Davidson, J.P., 1996. Deciphering mantle and crustal signatures in subduction zones. In: Berbout, G.E, Scholl, D.W., Kirby, S.H., Platt, J.P. (Eds.), Subduction: Top to Bottom. Geophysical Monographs, vol. 96. American Geophysical Union, pp. 251-262.

DePaolo, D.J., Linn, A.M., Schubert, G., 1991. The continental crustal age distribution: methods of determining mantle separation ages from $\mathrm{Sm}-\mathrm{Nd}$ isotopic data and application to the Southwestern United States. Journal of Geophysical Research B96, 2071-2088.

Eglington, B.M., 2006. Evolution of the Namaqua-Natal Belt, southern Africa - a geochronological and isotope geochemical review. Journal of African Earth Sciences 46, 93-111.

Escayola, M., Ramé, G., Kraemer, P.E., 1996. Caracterización y significado tectónico de las fajas ultramáficas de las Sierras Pampeans de Córdoba. $13^{\circ}$ Congreso Geológico Argentino, Actas III, pp. 421-438.

Escayola, M., Pimentel, M., Armstrong, R.A., 2005. A Neoproterozoic back-arc basin: SHRIMP U-Pb and $\mathrm{Sm}-\mathrm{Nd}$ isotopic evidence from the Eastern Pampean Ranges, Argentina. In: Pankhurst, R.J., Veiga, G.D. (Eds.), Gondwana 12: Geological and Biological Heritage of Gondwana, Abstracts. Academia Nacional de Ciencias, Córdoba, Argentina, p. 147.

Fernández Garrasino, C., Laffitte, G., Villar, H., 2005. Cuenca Chacoparanense. In: Chebli, G.A., Cortiñas, J.S., Spalletti, L.A., Legarretta, L., Vallejo, E.L. (Eds.), Frontera Exploratoria de la Argentina. $6^{\circ}$ Congreso de Exploración y Desarrollo de Hidrocarburos, pp. 97-114.

Finney, S., Gleason, J., Gehrels, G., Peralta, S., Aceñolaza, G., 2003. Early Gondwana connection for the Argentine Precordillera terrane. Earth and Planetary Science Letters 205, 349-359.

Finney, S., Gleason, J., Gehrels, G., Peralta, S., Aceñolaza, G., 2004. Corrigendum to "Early Gondwana connection for the Argentine Precordillera terrane". Earth and Planetary Science Letters 219, 413.

Frimmel, H.E., Fölling, P.G., 2004. Late Vendian closure of the Adamastor Ocean: timing of tectonic inversion and syn-orogenic sedimentation in the Gariep Basin. Gondwana Research 7, 685-699.

Frimmel, H.E., Frank, W., 1998. Neoproterozoic tectono-thermal evolution of the Gariep Belt and its basement, Namibia/South Africa. Precambrian Research 90, 1-28.

Frimmel, H.E., Hartnady, C.J.H., Koller, F., 1996. Geochemistry and tectonic setting of magmatic units in the Pan-African Gariep Belt, Namibia. Chemical Geology 130, 101-121.

Galindo, C., Casquet, C., Rapela, C., Pankhurst, R.J., Baldo, E., Saavedra, J., 2004. Sr, C and O-isotope geochemistry of carbonates from the area of Sierra de Pie de Palo, Argentina: stratigraphy and constraints on the origin of the Western Sierras Pampeanas. Precambrian Research 131, 55-71.

Gardini, C., Dalla Salda, L., 1997. El complejo metamórfico de la sierra de El Gigante, San Luis, Argentina. Revista de la Asociación Geológica Argentina 52, 132-142.

Gastal, M.C.P., Lafon, J.M., Hartmann, L.A., Koester, E., 2005. Sm$\mathrm{Nd}$ isotopic compositions as a proxy for magmatic processes during the Neoproterozoic of the southern Brazilian shield. Journal of South American Earth Sciences 18, 255-276.
Gaucher, C., Sial, A.N., Blanco, G., Sprechmann, P., 2004. Chemostratigraphy of the lower Arroyo del Soldado Group (Vendian Uruguay) and palaeoclimatic implications. Gondwana Research 7, 715-730.

Gaucher, C., Poiré, D.G., Gomez Peral, L., Chiglino, L., 2005. Litoestratigrafía, bioestratigrafía y correlaciones de las sucesiones sedimentarias del Neoproterozoico-Cámbrico del cratón del Río de la Plata (Uruguay y Argentina). Latin American Journal of Sedimentology and Basin Analysis 12, 145-190.

Gómez Peral, L., Poiré, D.G., Strauss, H., Zimmermann, U., 2007. Chemostratigraphy and diagenetic constraints on Neoproterozoic carbonate successions from the Sierras Bayas Group, Tandilia System, Argentina. Chemical Geology 237, 109-128.

Goodge, J.W., Williams, I.S., Myrow, P., 2004. Provenance of Neoproterozoic and lower Paleozoic siliciclastic rocks of the central Ross orogen, Antarctica: detrital record of rift-, passive-, and active-margin sedimentation. Geological Society of America Bulletin 116, 1253-1279.

Hall, H., Campal, N., Davis, D.W., Bossi, J., 2001. Magnetic studies and $\mathrm{U}-\mathrm{Pb}$ geochronology of the Uruguayan dyke swarm, Río de la Plata craton, Uruguay: paleomagnetic and economic implications. Journal of South American Earth Sciences 14, 349-361.

Hartmann, L.A., Delgado, I.M., 2001. Cratons and orogenic belts of the Brazilean shield and their contained gold deposits. Mineralium Deposita 36, 207-217.

Hartmann, L.A., Santos, J.O.S., Leite, J.A.D., McNaughton, N.J., 1999. Deepest exposed crust of Brazil - SHRIMP establishes three events. Geology 27, 947-950.

Hartmann, L.A., Piñeiro, D., Bossi, J., Leite, J.A.D., McNaughton, N.J., 2000. Zircon U-Pb SHRIMP dating of Palaeoproterozoic Isla Mala granitic magmatism in the Río de la Plata craton, Uruguay. Journal of South American Earth Sciences 13, 105-113.

Hartmann, L.A., Campal, N., Santos, J.O.S., McNaughton, N.J., Bossi, J., Schipilov, A., 2001. Archean crust in the Río de la Plata Craton, Uruguay-SHRIMP U-Pb reconnaissance geochronology. Journal of South American Earth Sciences 14, 557-570.

Hartmann, L.A., Santos, J.O.S., Bossi, J., Campal, N., Schipilov, A., McNaughton, N.J., 2002a. Zircon and titanite U-Pb SHRIMP geochronology of Neoproterozoic felsic magmatism on the eastern border of the Río de la Plata craton, Uruguay. Journal of South American Earth Sciences 15, 229-236.

Hartmann, L.A., Santos, J.O.S., Cingolani, C.A., McNaughton, N.J., 2002b. Two Palaeoproterozoic orogenies in the evolution of the Tandilia Belt, Buenos Aires, as evidenced by zircon U-Pb SHRIMP geochronology. Intemational Geology Review 44, 528-543.

Holland, T.J.B., Blundy, J., 1994. Non-ideal interactions in calcic amphiboles and their bearing on amphibole-plagioclase thermometry. Contributions to Mineralogy and Petrology 116, 433-447.

Iacumín, M., Piccirillo, E.M., Girardi, V.A.V., Teixeira, W., Bellieni, G., Etcheveste, H., Fernández, R., Pinese, J.P.P., Ribot, A., 2001. Early Proterozoic calc-alkaline and Middle Proterozoic tholeiitic dyke swarms from central-eastern Argentina: petrology, geochemistry, $\mathrm{Sr}-\mathrm{Nd}$ isotopes and tectonic implications. Journal of Petrology 42, 2109-2143.

Iñiguez, A.M., 1999. La cobertura sedimentaria de Tandilia. In: Caminos, R. (Ed.), Geología Argentina. Servicio Geológico Minero Argentino, Anales 29, pp. 101-106.

Jacobs, J., Thomas, R.J., 2004. Himalayan-type indenter-escape tectonics model for the southern part of the late Neopaleozoicearly Paleozoic East African-Antarctic orogen. Geology 32, $721-724$. 
Ježek, P., 1990. Análisis sedimentológico de la Formación Puncoviscana entre Tucumán y Salta. In: Aceñolaza, F.G., Millar, H., Toselli, A.J. (Eds.), El Ciclo Pampeano en el noroeste argentino. Serie Correlación Geológica $\mathrm{N}^{\circ} 4$. Universidad Nacional de Tucumán, pp. 9-35.

Ježek, P., Willner, A.P., Aceñolaza, F.G., Miller, H., 1985. The Puncoviscana trough - a large basin of Late Precambrian to Early Cambrian age on the Pacific edge of the Brazilian shield. Geologiches Rundschau 74, 573-584.

Kay, S.M., Orrell, S., Abruzzi, J.M., 1996. Zircon and whole-rock Nd$\mathrm{Pb}$ isotopic evidence for a Grenville age and Laurentian origin for the basement of the Precordillera in Argentina. Journal of Geology 104, 637-648.

Keppie, J.D, Bahlburg, H., 1999. Puncoviscana Formation of northwestern and central Argentina: passive margin or foreland basin deposit? In: Ramos, V.A., Keppie, J.D. (Eds.), LaurentiaGondwana connections before Pangea. Special Paper, vol. 336. Geological Society of America, pp. 139-143.

Kraemer, P.E., Escayola, M.P., Martino, R.D., 1995. Hipótesis sobre la evolución tectónica neoproterozoica de las Sierras Pampeanas de Córdoba $\left(30^{\circ} 40^{\prime}-32^{\circ} 40^{\prime}\right)$. Argentina. Revista de la Asociación Geológica Argentina 50, 47-59.

Kret2, R., 1983. Symbols for rock-forming minerals. American Mineralogist 68, 277.

Kröner, A., Cordani, U., 2003. African, southern Indian and South American cratons were not part of the Rodinia supercontinent: evidence from field relationships and geochronology. Tectonophysics 375, 325-332.

Lang, H.M., Wachter, A.J., Peterson, V.L., Ryan, J.G., 2004. Coexisting clinopyroxene/spinel and amphibole/spinel symplectites in metatroctolites of the Buck Creek ultramafic body, North Carolina Blue Ridge. American Mineralogist 89, 20-30.

Leal, P.E., Hartmann, L.A., Santos, O.S., Miró, R.C., Ramos, V.A., 2003. Volcanismo postorogénico en el extremo norte de las Sierras Pampeanas Orientales: nuevos datos geocronológicos y sus implicancias tectónicas. Revista de la Asociación Geológica Argentina 58, 593-607.

Leat, P.T., Larter, R.D., 2003. Intra-oceanic subduction systems: introduction. In: Larter, R.D., Leat, P.T. (Eds.), Intra-oceanic subduction systems. Tectonic and magmatic processes. Special Publication, vol. 219. Geological Society of London, pp. 1-17.

Leite, J.A.D., Hartmann, L.A., Fernandes, L.A.D., McNaughton, N.J., Soliani Jr., E., Koester, E., Santos, J.O.S., Vasconcellos, J.O.S., Vasconcellos, M.A.Z., 2000. Zircon U-Pb SHRIMP dating of the Dom Feliciano Belt, southernmost Brazil. Journal of South American Earth Sciences 13, 739-750.

Lira, R.R., Millone, H.A., Kirschbaum, A.M., Moreno, R.S., 1997. Calc-alkaline arc granitoid activity in the Sierra Norte-Ambargasta Ranges, central Argentina. Journal of South American Earth Sciences 10, 157-177.

Loewy, S.L., Connelly, J.N., Dalziel, I.W.D., 2004. An orphaned basement block: the Arequipa-Antofalla Basement of the central Andean margin of South America. Geological Society of America Bulletin 116, 171-187.

López de Luchi, M.G., Favetto, A., Pomposiello, C., Booker, J., 2005. Magnetotelluric evidence for the suture between the Río de la Plata and Pampean cratons at $31^{\circ} 40^{\prime} \mathrm{S}$, Córdoba province, Argentina. 6th International Symposium on Andean Geodynamics, Barcelona, Extended Abstracts, pp. 446-449.

Ludwig, K.R., 1999. Isoplot/Ex, a geochronological toolkit for Microsoft Excel.Berkeley Geochronological CenterSpecial Publication, vol. 1. version 2.31. 2455 Ridge Road, Berkeley, California 94709.
Ludwig, K.R., 2001. SQUID 1.02, A User's Manual; Berkeley Geochronology Center Special Publication No. 2, 2455 Ridge Road, Berkeley, CA 94709, US.

Ludwig, K.R., 2003. Isoplot/Ex Version 3.0: A Geochronological Toolkit for Microsoft Excel. Berkeley Geochronology Center Special Publication No. 4, 2455 Ridge Road, Berkeley CA 94709, USA.

Mángano, M.G., Buatois, L.A., 2004. Integración de estratigrafía secuencial, sedimentología e icnología para un análisis cronoestratigráfico del Paleozoico inferior del noroeste argentino. Revista de la Asociación Geológica Argentina 59, 273-280.

Mantovani, M.S.M., Brito Neves, B.B., 2005. The Parapanema lithospheric block: its importance for Proterozoic (Rodinia, Gondwana) supercontinent theories. Gondwana Research 8, 303-315.

Martino, R.D., 2003. Las fajas de deformación dúctil de las Sierras de Córdoba: una reseña general. Revista de la Asociación Geológica Argentina 58, 549-571.

McDonough, M.R., Ramos, V.A., Isachsen, C.E., Bowring, S.A., Vujovich, G.I., 1993. Edades preliminares de circones del basamento de la Sierra de Pie de Palo, Sierras Pampeanas occidentales de San Juán: sus implicancias para el supercontinente proterozoico de Rodinia. $12^{\circ}$ Congreso Geológico Argentino, Actas 3, pp. 340-342.

Nakamura, N., 1974. Determination of REE, Ba, Fe, $\mathrm{Mg}, \mathrm{Na}$ and $\mathrm{K}$ in carbonaceous and ordinary chondrites. Geochimica et Cosmochimica Acta 38, 757-773.

Omarini, R.H., Sureda, R.J., Gotze, H.J., Seilacher, A., Pluger, F., 1999. Puncoviscana folded belt in northwestern Argentina: testimony of Late Proterozoic Rodinia fragmentation and preGondwana collisional episodes. International Journal of Earth Sciences 88, 76-97.

Paces, J.B., Miller, J.D., 1993. Precise U-Pb ages of Duluth Complex and related mafic intrusions, northeastern Minnesota: geochronological insights to physical, petrogenetic, paleomagnetic, and tectonomagmatic process associated with the $1.1 \mathrm{Ga}$ Midcontinent Rift System. Journal of Geophysical Research B98, 13,997-14,013.

Pamoukaghlian, K., Gaucher, C., Bossi, J., Sial, A.N., Poiré, D.G., 2006. First $\mathrm{C}$ and $\mathrm{O}$ isotope data for the Piedras de Afilar Formation (Tandilia Terrane, Uruguay): their bearing on its correlation and age. V South American Symposium on Isotope Geology, Punta del Este, Uruguay. Short Papers, pp. 155-157.

Pankhurst, R.J., Rapela, C.W., 1995. Production of Jurassic rhyolite by anatexis of the lower crust of Patagonia. Earth and Planetary Science Letters 134, 23-36.

Pankhurst, R.J., Rapela, C.W., 1998. The Proto-Andean Margin of Gondwana: An Introduction. In: Pankhurst, R.J., Rapela, C.W. (Eds.), The Proto-Andean Margin of Gondwana. Special Publication, vol. 142. Geological Society of London, pp. 1-9.

Pankhurst, R.J., Rapela, C.W., Fanning, C.M., 2000. Age and origin of coeval TTG, I- and S-type granites in the Famatinian belt of NW Argentina. Transactions of the Royal Society of Edinburgh. Earth Sciences 91, 151-168.

Pankhurst, R.J., Ramos, A., Linares, E., 2003. Antiquity and evolution of the Río de la Plata craton in Tandilia, southern Buenos Aires province, Argentina. Journal of South American Earth Sciences 16, $5-13$.

Pankhurst, R.J., Rapela, C.W., Fanning, C.M., Márquez, M., 2006. Gondwanide continental collision and the origin of Patagonia. Earth Science Reviews 76, 235-257.

Peel, E., Preciozzi, F., 2006. Geochronologic synthesis of the Piedra Alta Terrane, Uruguay. V South American Symposium on Isotope Geology, Punta del Este, Uruguay. Short Papers, pp. 155-157. 
Piñán-Llamas, A., Simpson, C., 2006. Deformation of Gondwana margin turbidites during the Pampean orogeny, north-central Argentina. Geological Society of America Bulletin 118, 1270-1279.

Poiré, D.G., Spalletti, L.A., 2005. La cubierta sedimentaria precámbrica-paleozoica inferior del Sistema de Tandilia. In: de Barrio, R.E., Etcheverry, R.O., Caballé, M.F., Llambías, E. (Eds.), Geología y Recursos Minerales de la Provincia de Buenos Aires. Relatorio del $16^{\circ}$ Congreso Geológico Argentino, pp. 51-68.

Poiré, D.G., Spalletti, L.A., del Valle, A., 2003. The CambrianOrdovician siliciclastic platform of the Balcarce Formation (Tandilia System, Argentina): facies, trace fossils, palaeoenvironments and sequence stratigraphy. Geológica Acta 1, 41-60.

Porcher, C.C., Fernandes, L.A.D., Vujovich, G.I, Chernicoff, C.J., 2004. Thermobarometry, Sm/Nd ages and geophysical evidence for the location of the suture zone between Cuyania and Pampia terranes. In: Vujovich, G.I., Fernandes, L.A.D., Ramos, V.A. (Eds.), Cuyania: an exotic block to Gondwana. Gondwana Research, vol. 7, pp. 1057-1076.

Preciozzi, F., Basei, M.A.S., Masquelin, H., 1999. New geochronological data from the Piedra Alta Terrane (Río de la Plata Craton). II South American Symposium on Isotope Geology, Villa Carlos Paz, Argentina. Servicio Geológico Minero Argentino, Anales XXXIV, pp. 341-343.

Ramos, V.A., 1988. Late Proterozoic-early Paleozoic of South America - a collisional history. Episodes 11, 168-174.

Ramos, V.A., 1995. Sudamérica: un mosaico de continents y océanos. Ciencia Hoy 6, 24-29.

Ramos, V.A., Dallmeyer, R.D., Vujovich, G.I., 1998. Time constraints on the Early Palaeozoic docking of the Precordillera, central Argentina. In: Pankhurst, R.J., Rapela, C.W. (Eds.), The ProtoAndean Margin of Gondwana. Special Publication, vol. 142. Geological Society of London, pp. 143-158.

Ramos, V.A., Cristallini, E.O., Pérez, D.J., 2002. The Pampean flatslab of the Central Andes. Journal of South American Earth Sciences $15,59-78$.

Rapalini, A.E., 2005. The accretionary history of southern South America from the latest Proterozoic to the Late Paleozoic: some paleomagnetic constraints. In: Vaughan, A.P.M., Leat, P.T., Pankhurst, R.J. (Eds.), Terrane Processes at the Margins of Gondwana. Special Publication, vol. 243. Geological Society of London, pp. 305-328.

Rapalini, A.E., 2006. New late Proterozoic paleomagnetic pole for the Río de la Plata craton: implications for Gondwana. Precambrian Research 147, 223-233.

Rapela, C.W., 2000. The Sierras Pampeanas of Argentina: Paleozoic Building of the Southern Proto-Andes. In: Cordani, U.G., Milani, E.J., Thomaz-Filho, A., y Campos, D.A. (Eds.), Tectonic Evolution of South America, 31st International Geological Congress, pp. 381-387.

Rapela, C.W, Pankhurst, R.J., Casquet, C., Baldo, E., Saavedra, J., Galindo, C., Fanning, C.M., 1998. The Pampean Orogeny of the southern proto-Andes: evidence for Cambrian continental collision in the Sierras de Córdoba. In: Pankhurst, R.J., Rapela, C.W. (Eds.), The Proto-Andean Margin of Gondwana. Special Publication, vol. 142. Geological Society of London, pp. 181-217.

Rapela, C.W., Baldo, E.G., Pankhurst, R.J., Saavedra, J., 2002. Cordieritite and leucogranite formation during emplacement of highly peraluminous magma: the El Pilón Granite Complex (Sierras Pampeanas, Argentina). Journal of Petrology 43, 1003-1028.

Rapela, C.W., Pankhurst, R.J., Fanning, C.M., Grecco, L.E., 2003. Basement evolution of the Sierra de la Ventana Fold Belt: new evidence for Cambrian continental rifting along the southern margin of Gondwana. Journal of the Geological Society, London 160, 613-628.

Rapela, C.W., Pankhurst, R.J., Casquet, C., Fanning, C.M., Galindo, C., Baldo, E., 2005. Datación U-Pb SHRIMP de circones detríticos en paranfibolitas neoproterozoicas de las secuencia Difunta Correa (Sierras Pampeanas Occidentales, Argentina). Geogaceta 38, 3-6.

Rozendaal, A., Gresse, P.G., Scheepers, R., Le Roux, J.P., 1999. Neoproterozoic to Early Cambrian crustal evolution of the PanAfrican Saldania belt. South Africa. Precambrian Research 97, 303-323.

Russo, A., Ferello, R., Chebli, G., 1979. Llanura Chaco-Pampeana. Segundo Simposio de Geología Regional Argentina, Córdoba, Tomo I, pp. 139-183.

Saalman, K., Remus, M.V.D., Hartmann, L.A., 2006. Tectonic evolution of the Neoproterozoic São Gabriel block, southern Brazil: constraints on Brasiliano orogenic evolution of the Río de la Plata cratonic margin. Journal of South American Earth Sciences 21, 204-227.

Sambridge, M.S., Compston, W., 1994. Mixture modeling of multicomponent data sets with application to ion-probe zircon ages. Earth and Planetary Science Letters 128, 373-390.

Santos, J.O., Hartmann, L.A., Bossi, J., Campal, N., Schipilov, A., Piñeiro, McNaughton, N.J., 2003. Duration of the TransAmazonian Cycle and its correlation with in South America based on U-Pb SHRIMP geochronology of the La Plata craton, Uruguay. International Geology Review 45, 27-48.

Sato, A.M., Tickyj, H., Llambaís, E.J., Sato, K., 2000. The Las Matras tonalitic-trondhjemitic pluton, central Argentina: Grenvillian-age constraints, geochemical characteristics, and regional implications. Journal of South American Earth Sciences 13, 587-610.

Scheepers, R., Annstrong, R., 2002. New U-Pb SHRIMP zircon ages of the Cape Granite Suite: implications for the magmatic evolution of the Saldania Belt. South African Joumal of Geology 105, 241-256.

Schwartz, J.J., Gromet, L.P., 2004. Provenance of Late Proterozoicearly Cambrian basin, Sierras de Córdoba, Argentina. Precambrian Research 129, 1-21.

Sims, J.P., Ireland, T.R., Cmacho, A., Lyons, P., Pieters, P.E., Skirrow, R.G., Stuart-Smith, P.G., Miró, R., 1998. U-Pb, Th-Pb and Ar-Ar geochronology form the southern Sierras Pampeanas: implication for the Palaeozoic tectonic evolution of the western Gondwana margin. In: Pankhurst, R.J., Rapela, C.W. (Eds.), The ProtoAndean Margin of Gondwana. Special Publication, vol. 142. Geological Society of London, pp. 259-281.

Smith, I.E., Worthington, T.J., Stewart, R.B., Price, R.C., Gamble, J.A., 2003. Felsic volcanism in the Kermadec arc, SW Pacific: crustal recycling in an oceanic setting. In: Larter, R.D., Leat, P.T. (Eds.), Intra-oceanic subduction systems: tectonic and magmatic processes. Special Publication, vol. 219. Geological Society of London, pp. 99-118.

Squire, R.J., Campbell, I.H., Allen, C.M., Wilson, C.J.L., 2006. Did the Transgondwanan Supermountain trigger the explosive radiation of animals on Earth? Earth and Planetary Science Letters 250, $116-133$

Steenken, A., Siegesmund, S., López de Luchi, M.G., Frei, R., Wemmer, K., 2006. Neoproterozoic to Early Palaeozoic events in the Sierra de San Luis: implications for the Famatinian geodynamics in the Eastern Sierras Pampeanas (Argentina). Journal of the Geological Society, London 163, 965-982.

Sun, S.-S., McDonough, W.F., 1989. Chemical and isotopic systematics of oceanic basalts: implication for mantle 
compositions and processes. In: Saunders, A.D., Norry, M.J. (Eds.), Magmatism in the ocean basins. Special Publication, vol. 42. Geological Society of London, pp. 313-345.

Teixeira, W., Pinese, J.P.P., Iacumin, M., Girardi, V.A.V., Piccirillo, E.M., Etcheveste, H., Robot, A., Fernandez, R., Renne, P.R., Heaman, L.M., 2002. Calc-alkaline and tholeiitic dyke swarms of Tandilia, Río de la Plata craton, Argentina: U-Pb, Sm-Nd, and $\mathrm{Rb}-\mathrm{Sr} 40 \mathrm{Ar} / 39 \mathrm{Ar}$ data provide new clues for intraplate rifting shortly after the Trans-Amazonian orogeny. Precambrian Research 119, 329-353.

Teruggi, M.E., 1964. Paleocorrientes y paleogeografía de las ortocuarcitas de la Serie de La Tinta (provincia de Buenos Aires). Anales de la Comisión de Investigaciones Científicas de la provincia de Buenos Aires 5, 1-27.

Thomas, W.A., Astini, R.A., 2003. Ordovician accretion of the Argentine Precordillera terrane to Gondwana: a review. Journal of South American Earth Sciences 16, 67-79.

Tohver, E., D'Agrella-Filho, M.S., Trindade, R.I.F., 2006. Paleomagnetic record of Africa and South America for the 1200-500 Ma interval, and evaluation of Rodinia and Gondwana assemblies. Precambrian Research 147, 193-222.

Tollo, R.P., Aleinikoff, J.N., Bartholomew, M.J., Rankin, D.W., 2004. Neoproterozoic A-type granitoids of the central and southern Appalachians: intraplate magmatism associated with episodic rifting of the Rodinian supercontinent. Precambrian Research $128,3-38$.

Trindade, R.I.F., D'Agrella-Filho, M.S., Epof, I., Brito Neves, B.B., 2006. Paleomagnetism of Early Cambrian Itabaiana mafic dikes (NE Brazil) and the final assembly of Gondwana. Earth and Planetary Science Letters 244, 361-377.

Varela, R., Sato, A., Basei, M.A.S., Siga Jr., O., 2004. Proterozoico medio y Paleozoico inferior de la Sierra de Umango, antepais andino $\left(29^{\circ} \mathrm{S}\right)$, Argentina: edades $\mathrm{U}-\mathrm{Pb}$ y caracterizaciones isotópicas. Revista Geológica de Chile 30, 265-284.

Verdecchia, S.O., Baldo, E.G., Benedetto, J.L., Borghi, P.A., 2007. The first shelly faunas from metamorphic rocks of the Sierras Pampeanas (La Cébila Formation, Sierra de Ambato, Argentina): age and paleogeographic implications. Ameghiniana 44. von Gosen, W., Prozzi, C., 2005. Clastic metasediments in the Sierras Norte de Córdoba (Argentina): Pampean compression and magmatism. XVI Congreso Geológico Argentino, Actas 1, pp. 247-248.

Vujovich, G.I., Van Staal, C.R., Davis, W., 2004. Age constraints and the tectonic evolution and provenance of the Pie de Palo Complex, Cuyania composite terrane, and the Famatinian orogeny in the Sierra de Pie de Palo, San Juán, Argentina. Gondwana Research 7, 1041-1056.

Webster, R.E., Chebli, G.A., Fischer, J.F., 2004. General Levalle basin, Argentina: a frontier Lower Cretaceous rift basin. AAPG Bulletin $88,627-652$.

Williams, I.S., 1998. U-Th-Pb Geochronology by Ion Microprobe. In: McKibben, M.A., ShanksIII III, W.C., Ridley, W.I. (Eds.), Applications of microanalytical techniques to understanding mineralizing processes. Reviews of Economic Geology, vol. 7, pp. 1-35.

Willner, A.P., Toselli, A.J., Bazán, C., Vides de Bazán, M.E., 1983. Rocas metamórficas. In: Aceñolaza, F.G., Miller, H., Toselli, A. (Eds.), Geología de la Sierra de Ancasti. Münstersche Forschungen zur Geologie und Paläontologie, vol. 59, pp. 31-78.

Winn, R.D., Steinmetz, J.C., 1998. Upper Paleozoic strata of the Chaco-Paraná basin, Argentina, and the great Gondwana glaciation. Journal of South American Earth Sciences 11, $153-168$.

Wood, D.A., 1980. The application of a Th-Hf-Ta diagram to problems of tectonomagmatic classification and to establishing the nature of crustal contamination of basaltic lavas of the British Tertiary Volcanic Province. Earth and Planetary Science Letters 50, 11-30.

Zimmermann, U., 2005. Provenance studies of very low- to low-grade metasedimentary rocks of the Puncoviscana complex, northwest Argentina. In: Vaughan, A.P.M., Leat, P.T., Pankhurst, R.J. (Eds.), Special Publication, vol. 246. Geological Society of London, pp. 381-416. 